\title{
WestVirginiaUniversity
}

THE RESEARCH REPOSITORY @ WVU

Graduate Theses, Dissertations, and Problem Reports

2008

\section{Analysis of underground coal mine refuge shelters}

Mickey D. Mitchell

West Virginia University

Follow this and additional works at: https://researchrepository.wvu.edu/etd

\section{Recommended Citation}

Mitchell, Mickey D., "Analysis of underground coal mine refuge shelters" (2008). Graduate Theses, Dissertations, and Problem Reports. 1937.

https://researchrepository.wvu.edu/etd/1937

This Thesis is protected by copyright and/or related rights. It has been brought to you by the The Research Repository @ WVU with permission from the rights-holder(s). You are free to use this Thesis in any way that is permitted by the copyright and related rights legislation that applies to your use. For other uses you must obtain permission from the rights-holder(s) directly, unless additional rights are indicated by a Creative Commons license in the record and/ or on the work itself. This Thesis has been accepted for inclusion in WVU Graduate Theses, Dissertations, and Problem Reports collection by an authorized administrator of The Research Repository @ WVU. For more information, please contact researchrepository@mail.wvu.edu. 


\title{
Analysis of Underground Coal Mine Refuge Shelters
}

\author{
Mickey D. Mitchell
}

\author{
Thesis submitted to the \\ College of Engineering and Mineral Resources \\ at West Virginia University \\ in partial fulfillment of the requirements \\ for the degree of \\ Master of Science \\ in \\ Mining Engineering
}

Felicia F. Peng

Keith A. Heasley

Syd S. Peng

Department of Mining Engineering

\author{
Morgantown, West Virginia \\ 2008
}

Keyword: Underground Coal Mine Refuge Shelters, Mining Engineering, Coal Mine Safety 


\section{ABSTRACT \\ Analysis of Underground Coal Mine Refuge Shelters \\ Mickey D. Mitchell-Cline}

This thesis summarizes the technique used to build underground coal refuge shelters and their availabilities. The first step is to discuss the manufacturers of the shelter and the types that they can provide. Next, the requirements set forth by the West Virginia Office of Miners Health, Safety and Training (WVOMHST) and Mine Safety and Health (MSHA) regarding the design of the shelters/chambers are examined.

The first specification examined is whether or not the shelters/chambers can withstand a 15 psi overpressure. This is determined by using techniques used in the analysis of rectangular steel beams and steel sheets. The equations used for this analysis are provided by the American Institute of Steel Construction (AISC). The end result is the calculation of a safety factor that determines if the steel rectangular beams or steel sheets will survive a 15 psi pressure that may result from an explosion.

The second specification examined is the air quality/quantity requirements. The WVOMHST requires that an internal shelter atmosphere contain at least 19.5 percent oxygen, $<0.5$ percent carbon dioxide, and carbon monoxide levels must not be above 50 parts per million (ppm). The ability of the chambers to maintain these requirements are examined using the respiratory quotient technique. Also, the ability of the shelters/chamber to dilute high carbon monoxide and carbon dioxide levels are examined.

Finally, the WVOMHST require that the shelters/chambers be capable of maintaining an apparent internal temperature of 95 degrees fahrenheit. The shelters/chambers ability to do this are examined using a technique common to the American Society of Refrigeration and Air Conditioning Engineers ASHRAE). The 
process used determines the specific humidity and temperature of the internal atmosphere of a shelter/chamber. Using these calculations the heat index, also known as apparent temperature, is determined. 


\section{ACKNOWLEDGEMENTS}

The author of this thesis would like to express his sincere appreciation to those who have contributed to the contents of this thesis. Particular thanks go to:

Associate Professor Felicia F. Peng, thesis co-advisor, for her guidance, encouragement, assistance, and advice during the development of this thesis;

Professor Keith A. Heasley, thesis co-advisor, for his guidance, encouragement, assistance, and advice throughout the development of this thesis;

The West Virginia University, Department of Mining Engineering and the West Virginia Coal and Energy Research Bureau (WVCERB) for partial financial support of this research; 


\section{Table of Contents}

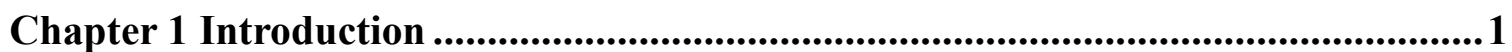

Chapter 2 BACKGROUND...................................................................................2

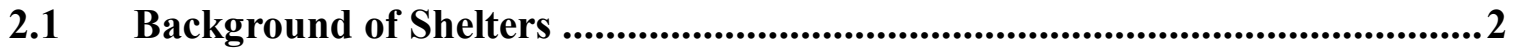

2.2 Currently Available Underground Coal Mine Refuge Shelters ......................4

2.2.1 The Kennedy Shelter ..................................................................................4

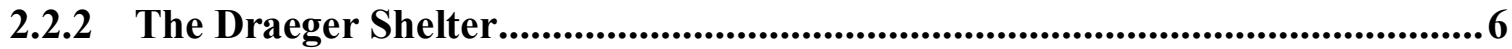

2.2.3 The Modern Mine Supply Shelter ................................................................6

2.2.4 The MineArc Shelter ................................................................................

2.2.5 The Strata Products Shelter .................................................................9

2.2.6 The Chem-Bio Shelter ......................................................................................... 11

2.3 A Future Proposal To Support Underground Coal Mine Emergencies ........ 12

2.4 The Shelters Approved in the state of West Virginia .................................... 13

Chapter 3 Structural Analysis of Shelters ........................................................16

3.1 Structural Analysis of Hard-Walled Shelters .......................................... 16

3.1.1 Analysis of Steel Beam Structure in Hard-Walled Shelters.........................17

3.1.2 Roof Beam Structure Analysis of Hard-Walled Shelters ................................20

3.1.3 Sidewall and End-Wall Structure Analysis of Hard-walled Shelters ............24

3.1.4 Floor Structure Analysis of Hard-Walled Shelters ...................................26

3.1.5 Steel Sheet Analysis of Hard-Walled Shelters .............................................27

3.1.6 Steel Door Analysis of Hard-Walled Shelters .............................................28

3.1.7 Hard-Walled Shelter Window Analysis ........................................................30

3.2 Structure Analysis of Soft-Walled Shelters ................................................31

3.2.1 Beam Structure Analysis of Steel Skid Container Roof and Floor .................33

3.2.2 Sidewall and End-Wall Structure Analysis of Steel Skid Container ..............34 
3.2.3 Steel Sheet Analysis of Steel Skid Container ............................................35

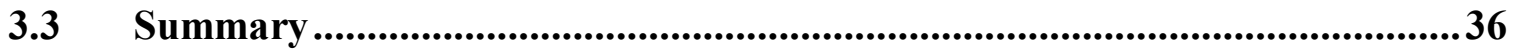

CHAPTER 4 Air Quality inside Shelters .......................................................37

4.1 MSHA Requirements for Providing Oxygen ............................................37

4.2 Oxygen Parameters................................................................................38

4.2.1 Carbon Monoxide Parameters .................................................................43

4.2.2 Carbon Dioxide Parameters .................................................................... 44

Chapter 5 Temperature Requirements Inside Shelters .............................................50

5.1 Procedure for Determining the Apparent Temperature ....................................50

Appendix A-1 Some Quality Properties of Available Underground Coal Refuge Shelter ........................................................................................................................60

Appendix A-2 A list of Underground Refuge Shelter Requirements in the state of WV ............................................................................61

Appendix B-1 Beam Diagrams and Formulas for Simply Supported Beams with a Uniformly Distributed Load ...................................................................................63

Appendix B-2 Availability of shapes, plates, and bars according to ASTM structural steel specifications, ............................................................................................64

Appendix B-3 Formulas for flat plates with straight boundaries and constant

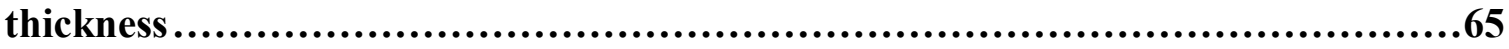

Appendix C-1 MSHA Specifications for Quantity of Breathable Air (MSHA, 2007)..................................................................................................66

Appendix C-2 MSHA Specifications for Supplying Breathable Air (MSHA,

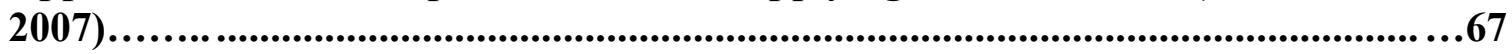

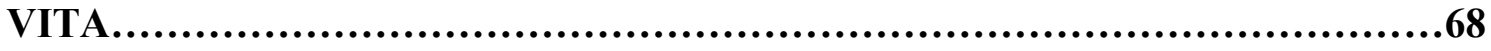

REFERENCES................................................................69 


\section{List of Figures}

Figure 2-1. The Kennedy Shelter ................................................................................5

Figure 2-2. The Draeger Shelter .....................................................................5

Figure 2-3. The Hard-Walled Shelter/Chamber built by Modern Mine Safety

Supply.........................................................................................................................

Figure 2-3. The MineARC CRM64 Shelter...................................................................8

Figure 2-4a. The MineArc CRM24 Shelter .........................................................8

Figure 2-4b. The MineArc CRM24 Shelter with hydraulic roof ...............................9

Figure 2-5. The Hard-Walled Coal Mine Refuge Shelter by Strata .........................10

Figure 2-6. The Fresh Air Bay Soft-Walled Shelter by Strata................................10

Figure 2-7. The LifeShelter by ChemBio Inc. ........................................................11

Figure 2-8 Survivair Puma SCBA mask............................................................12

Figure 3-1. Schematic of a Hard-Walled Shelter ...............................................17

Figure 3-2. Dimensions of Underground Shelters .............................................21

Figure 3-3 Cross section view of tubing beams. .................................................22

Figure 3-4. Steel Shelter Door Diagram. ..........................................................29

Figure 3-5 Sidewall view of Steel Skid Container ................................................32

Figure 3-6 Endwall view of Steel Skid Container...............................................33

Figure 4.1 Lithium Hydroxide (LiOH) Absorption Curves....................................48 


\section{List of Tables}

Table 3.1 Dimensions and Properties of Steel Rectangular Beams in the Roof ........23

Table 3.2 Stress Formula Outputs of Beams in the Roof...........................................23

Table 3.3 Dimensions and Properties of Steel Rectangular Beams in the Sidewalls.25

Table 3.4 Stress Formula Outputs of Beams in the Sidewalls ................................25

Table 3.5 Dimensions and Properties of Steel Rectangular Beams in the End-Walls

Table 3.6 Stress Formula Outputs of Beams in the End-Walls ...............................25

Table 3.7 Dimensions and Properties of Steel Rectangular Beams in the Floor .......26

Table 3.8 Stress Formula Outputs of Beams in the Floor ...........................................26

Table 3.9 Dimensions and Properties of Steel Rectangular Beams in the Door........30

Table 3.10 Stress Formula Outputs of Beams in the Door .....................................30

Table 3.11 Dimensions and Properties of the Windows .............................................31

Table 3.12 Stress Formula Outputs for the Window .................................................31

Table 3.13 Dimensions and properties of Steel Rectangular Tubes in the Roof and Floor ...............................................................................................................34

Table 3.14 Stress Formula Outputs of Beams for the Roof and Floor .....................34

Table 3.15 Dimensions and Properties of Steel Rectangular Tubes Used in the Sidewalls and End-Walls...............................................................................................35

Table 3.16 Stress Formula Outputs of Beams for the Sidewalls and End-Walls ......35

Table 4.1 Composition of Normal Air ......................................................................39

Table 4.2 The Effects of an Oxygen Depleted Atmosphere....................................39

Table 4.3 Air Quality of Grade D Compressed Oxygen Cylinders .............................41

Table 4.4 Effects of Carbon Monoxide (CO) Poisoning ...............................................44

Table 4.5 The Physiological Effects of High Concentrations of Carbon Dioxide......46 


\section{Chapter 1}

\section{Introduction}

On January 2, 2006, in Talmansville, West Virginia (WV) an explosion occurred at the Sago Mine in which 13 miners were trapped approximately two miles underground. Twelve of the miners never made it out of the mine alive, only one survived. Only seventeen days after this accident, on January 19, 2006, a belt fire broke out at the Aracoma mine in Melville, West Virginia that resulted in the loss of life for two more coal miners. As a result of these two incidents, the Miner Act of 2006 was signed into law on June 15, 2006. This Act was an upgrade to the mine rescue processes as it called for major reform in the areas of post emergency event equipment used, such as tracking devices, larger breathable air stockpiles and communications.

With the passing of the Miner Act of 2006, the Mine Safety and Health Administration (MSHA) now requires that post accident breathable air be supplied for all miners underground for a period not less than 96 hours (MSHA, 2007). There are several ways this can be accomplished such as: creating larger oxygen stockpiles in the mines, drilling boreholes from the surface through the roof of the mine as it advances, or of placing an underground refuge shelter in the mine.

The West Virginia Office of Miners' Health, Safety and Training (WVOMHST) passed a new law on March 9, 2007 requiring the use of refuge shelters in WV underground coal mines (WVOMHST, 2007). This report will evaluate the shelters based on type, availability, structural integrity, and the ability to sustain life. 


\section{Chapter 2}

\section{BACKGROUND}

This chapter focuses on the current use of underground shelters throughout the mining industry worldwide and the various types of shelters that are being proposed for West Virginia coal mines. The currently available shelters and those that were approved by the West Virginia Office of Miners' Health Safety and Training (WVOMHST) will be analyzed.

\subsection{Background of Shelters}

In the event of an emergency, such as a flood or fire, miners may become endangered or trapped. A response plan for these types of events must provide miners a safe haven, in particularly during a coal mine fire or explosion when the ventilation can be polluted with toxic gases very quickly. In these types of situations miners can quickly become disarrayed and possibly injured, so provisions must be made in the emergency plan for both self escapes and aided escape. Mine emergency response procedures must therefore include self escape plans, as well as rescue plans, which provide a means for miners to pass through or seek shelter in atmospheres that may not support life.

One of the key factors to consider in this process is the need for a safe place located close to each working section in the mine that can be used where miners can rest, re-equip, communicate and/or wait for help. These locations should be pre-planned and located at strategic locations throughout a mine. 
Historically, in metal mines in Canada, emergency plans have included refuge shelters where miners can seek shelter with adequate provisions and communications until either the danger has passed or they are rescued. A typical scenario of this type in a metal mine would be during a diesel powered vehicle fire which may pollute the atmosphere endangering life for a finite time until it is burned out and the atmosphere becomes safe again. However, a similar fire in an underground coal mine could ignite other material around it such as conveyor belting or even the coal seam itself. In this case the fire could rapidly become deep-seated and last for several days or even weeks.

The natural instinct of an underground miner in an emergency situation such as a fire or explosion is to get to a safe place as fast as possible such as a fresh air base or the surface and this is normally the best thing to do. This is especially relevant in an underground coal mine, where in the event of fire the coal seam walls of underground roadways are themselves fuel and may burn for a long time once they are ignited. The provision of refuge shelters may go against this general principle as it encourages miners to stay underground. Therefore questions rise such as under what circumstances would refuge shelters be beneficial to use in underground coal mines.

There are several circumstances where the use of refuge shelters can be beneficial in coal mines. Some of these include situations such as during an emergency event there is a long distance to a fresh air base from the working section, elevated temperatures, restricted egress and at times when a self contained breathing rescuer (SCSR) has ran out of air (DJF, 1004). In an effort to protect miners in these types of emergency situations the placement of the shelters will require clearly planned procedures, good training, and review of technical considerations such as ventilation, communications, welfare, and feeding. 


\subsection{Currently Available Underground Coal Mine Refuge Shelters}

In 2006 there were several mining accidents that took place that alerted lawmakers that after emergency protection in underground coal mines is needed. Most notably of these events were the Sago and Aracoma accidents that occurred in West Virginia. Prior to these events only Canada, South Africa, and Japan required the use of refuge shelters in their underground coal mines (DJF, 2004). After the tragic events of 2006, the U.S. started looking into the use of refuge shelters in their coal mines. Shortly thereafter legislation was passed to allow for the use of underground refuge shelters. This has persuaded many companies to work quickly to establish themselves as underground coal mine refuge shelter suppliers.

There are currently several companies producing shelters for underground coal mines and the two types currently being manufactured are the hard-walled and softwalled shelters. The hard-walled shelter is typically being made of A46 steel while the soft-walled type is typically constructed of flame retardant inflatable material. Some of the current manufacturers only make the hard-walled while others make both the hardwalled and soft-walled. This is beneficial to the mine operators in that they can better choose a refuge shelter based on their mines conditions. Each available shelter and their individual abilities will be discussed below.

\subsubsection{The Kennedy Shelter}

The Kennedy Shelter is built by Jack Kennedy Metal Products \& Buildings Inc. The Kennedy Chamber is a hard-walled shelter that can be used as a life support system during an emergency event in an underground coal mine. The Shelter is skid plate 
mounted that allows it to be easily moved around a mine without concern of damaging the unit and it can support a range of 10 - 33 miners for at least 96 hours (WVOMHST, 2007). Generally, all the miners have to do is enter the shelter to start the oxygen flow. A view of the Kennedy hard-walled shelter is given in Figure 2-1 (MSHA, 2006).

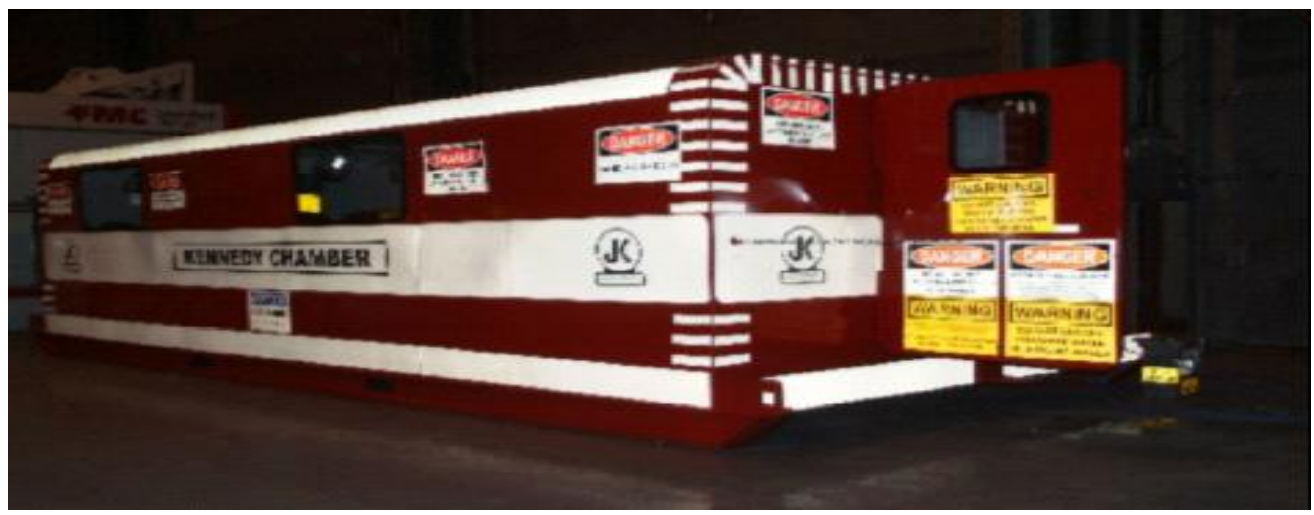

Figure 2-1. The Kennedy Shelter (MSHA, 2006)

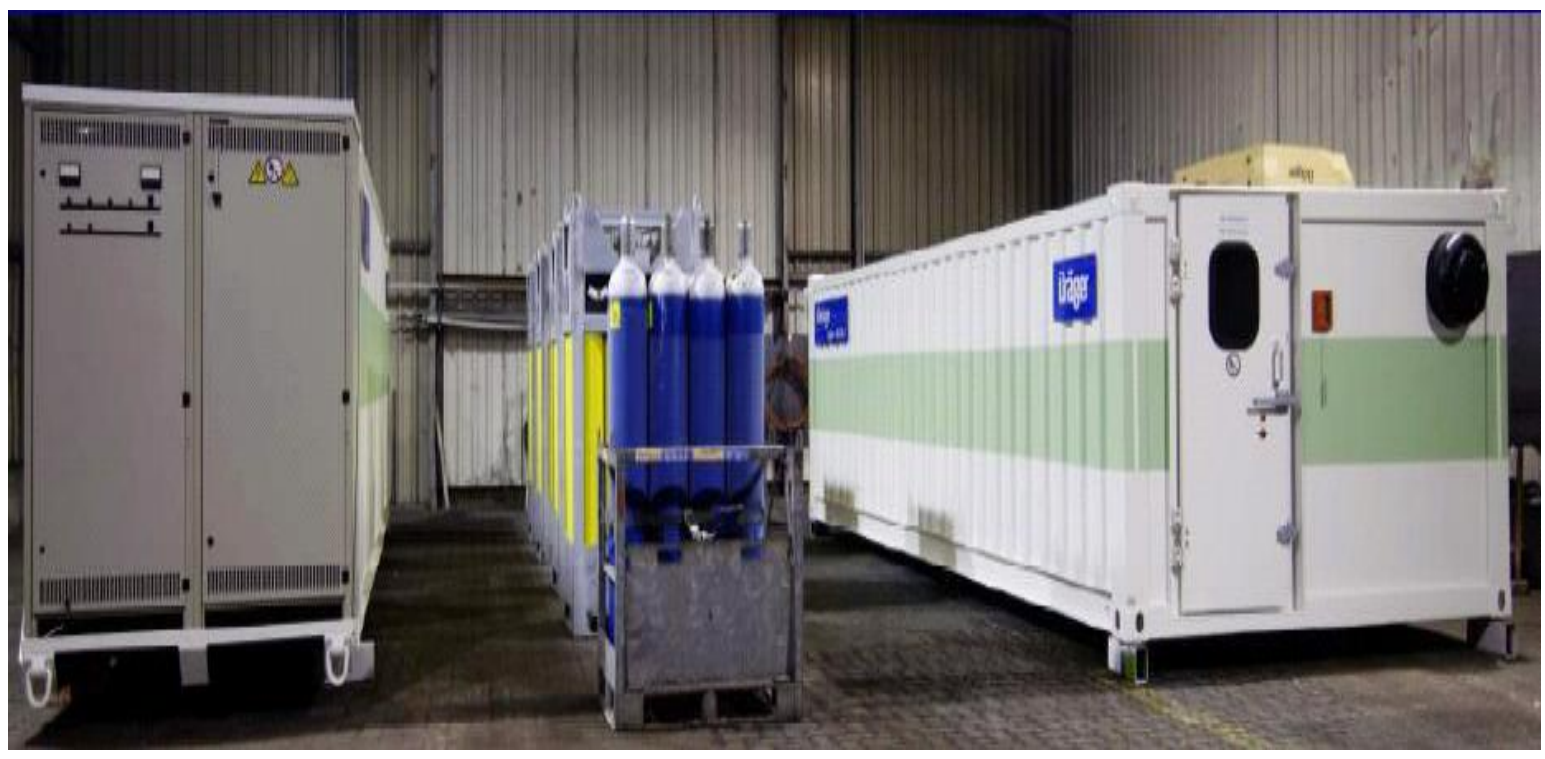

Figure 2-2. The Draeger Shelter (MSHA, 2006) 


\subsubsection{The Draeger Shelter}

The Draeger Emergency Shelter is the second type of shelter, and it is manufactured by Draeger Safety Inc. The Draeger Shelter is the hard-walled type and comes in two different sizes that can support up to 10 to 16 miners for a period of at least 96 hours (WVOMMHST, 2007). The Draeger shelter can be built to a required specification according to site conditions. They are designed to offer protection to the users by creating a respirable atmosphere inside an enclosed place. The Draeger Shelter is shown in Figure-2-2.

\subsubsection{The Modern Mine Supply Shelter}

Another company that makes the hard-walled shelters is Modern Mine Safety Supply, LLC. The Modern Mine Supply Refuge Shelter is the hard-walled type and is made to be used by up to 16 miners and can support their lives for at least 96 hours (WVOMHST, 2007). This shelter was designed specifically for the unique needs of underground coal operations and is customizable. A look at the Modern Mine Supply Refuge Chamber is given in Figure 2-3. 




Figure 2-3. The Hard-Walled Shelter built by Modern Mine Safety Supply (MSHA, 2006)

\subsubsection{The MineArc Shelter}

Another manufacturer of underground coal refuge shelters is the Mine-Arc Systems company based in Australia. In the past they have been involved in providing solutions to underground safety requirements primarily in metal mines. Mine-Arc currently has two hard-walled units designed and they include the CRM64 and the CRM24. The CRM64 is fitted onto a skid plate with towing and lifting points. The CRM24 can be more compactly stored as it comes folded and fitted with steel wheels for towing. The CRM24 comes with a hydraulic roof that can be adjusted from 2 feet to 6 feet. A view of the CRM64 is provided in Figure 2-3 and a view of the CRM24 is given in figures $2-4 a$ and $2-4 b$. 


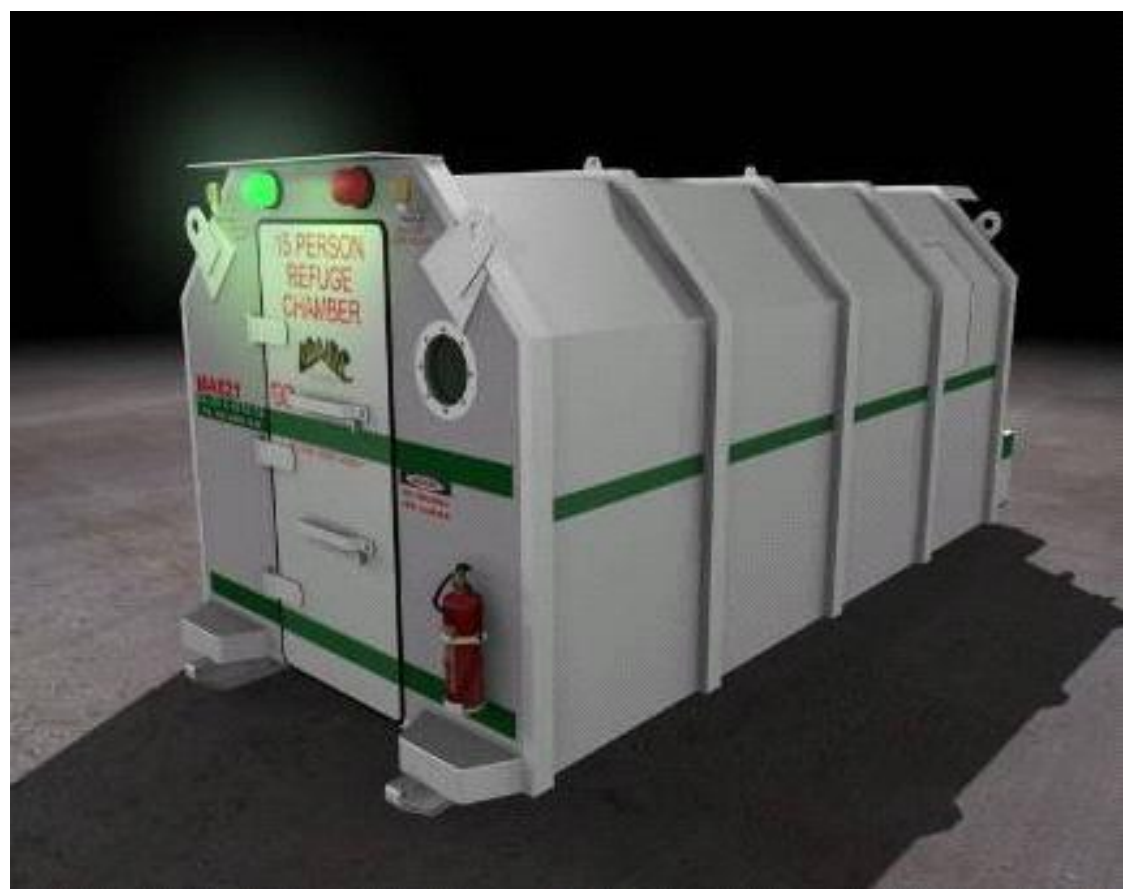

Figure 2-3. The MineARC CRM64 Shelter (MSHA, 2006)



Figure 2-4a. The MineArc CRM24 Shelter (MSHA, 2006) 


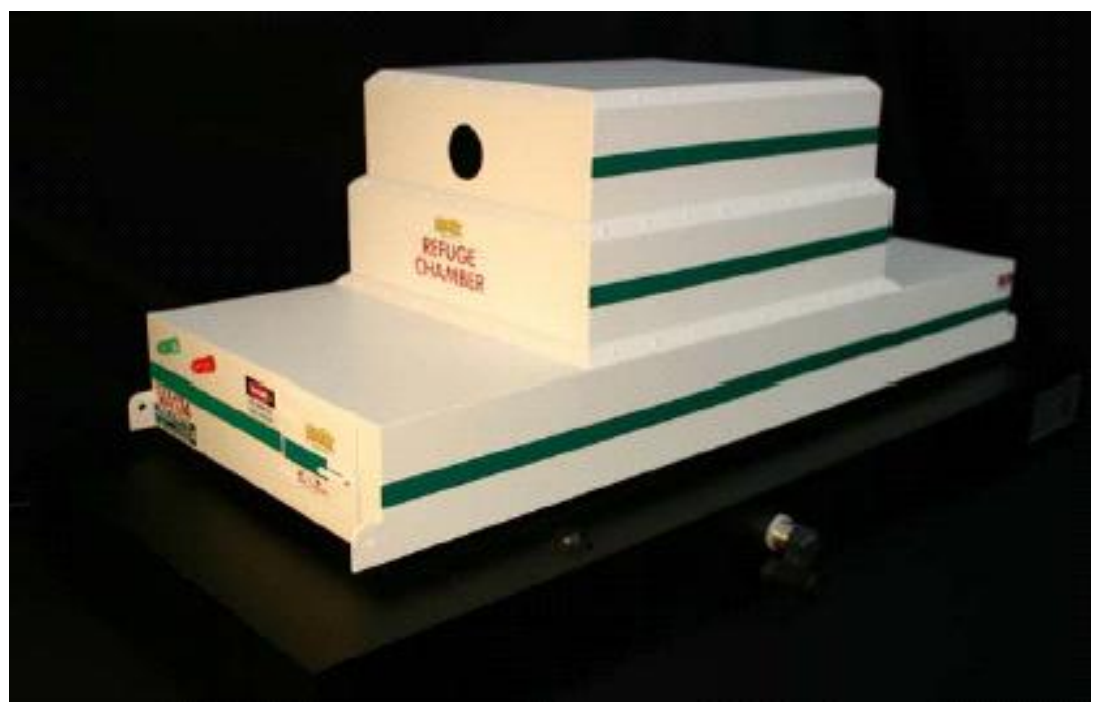

Figure 2-4b. The MineArc CRM24 Shelter with hydraulic roof, (MSHA, 2006).

\subsubsection{The Strata Products Shelter}

A company that makes a lot of equipment for the metal and coal mining industry also has decided to venture into the underground coal mine refuge shelter business. The company is Strata Products Inc. and they manufacture both the hard-walled and softwalled type of shelters. They call their hard-walled type "The Coal Mine Refuge Shelter" and orders can be made to accommodate 20,16 , or 8 miners. The soft-walled type Strata makes is called "The Fresh Air Bay" and can be custom ordered to accommodate 20, 16, or 10 miners. Both the hard-walled and soft-walled type can support life for at least 96 hours (WVOMHST, 2007). A view of the hard-walled shelter is given in Figure 2-5 and a view of the soft-walled shelter in Figure 2-6. 


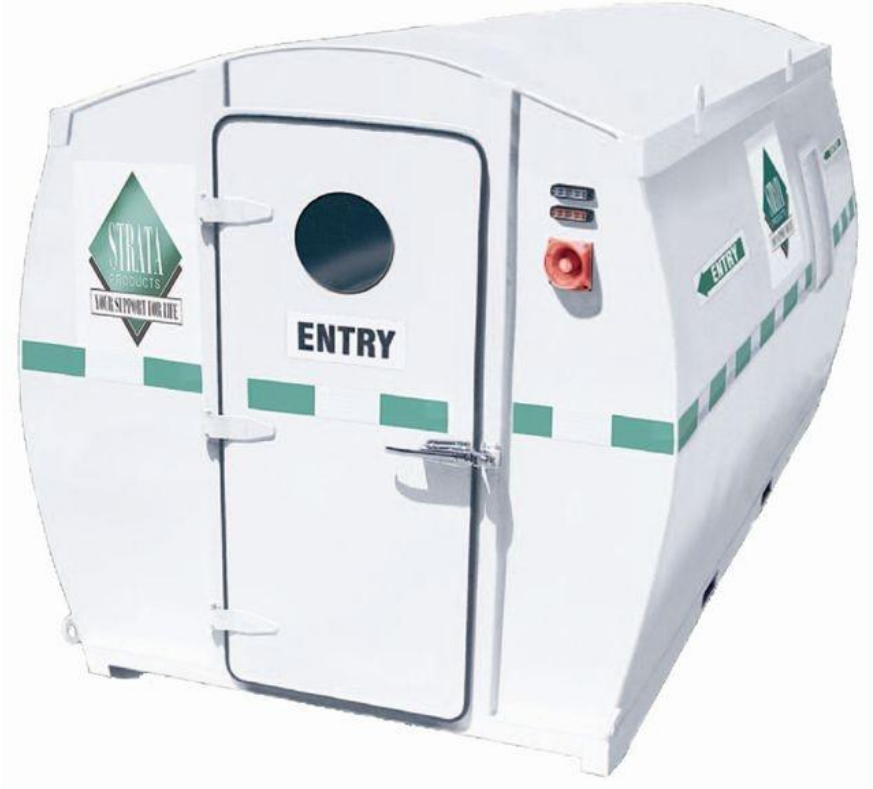

Figure 2-5. The Hard-Walled Coal Mine Refuge Shelter by Strata (Strata, 2007)



Figure 2-6. The Fresh Air Bay Soft-Walled Shelter by Strata (Strata, 2007) 


\subsubsection{The Chem-Bio Shelter}

Another type of refuge shelter being manufactured is Chem-Bio Shelter Inc.'s the Life-Shelter. The Life-Shelter is a soft-wall type and can support from 10 to 30 miners. This soft-walled shelter is placed in a steel skid container that allows it to be moved around in an underground coal mine, and the shelter uses air beam technology that enables it to be easily deployed. The refuge shelter can also support life for the amount of miners it is designed to accommodate for a total of at least 96 hours (WVOMHST, 2007). A view of the Life-Shelter is given in Figure 2-7.

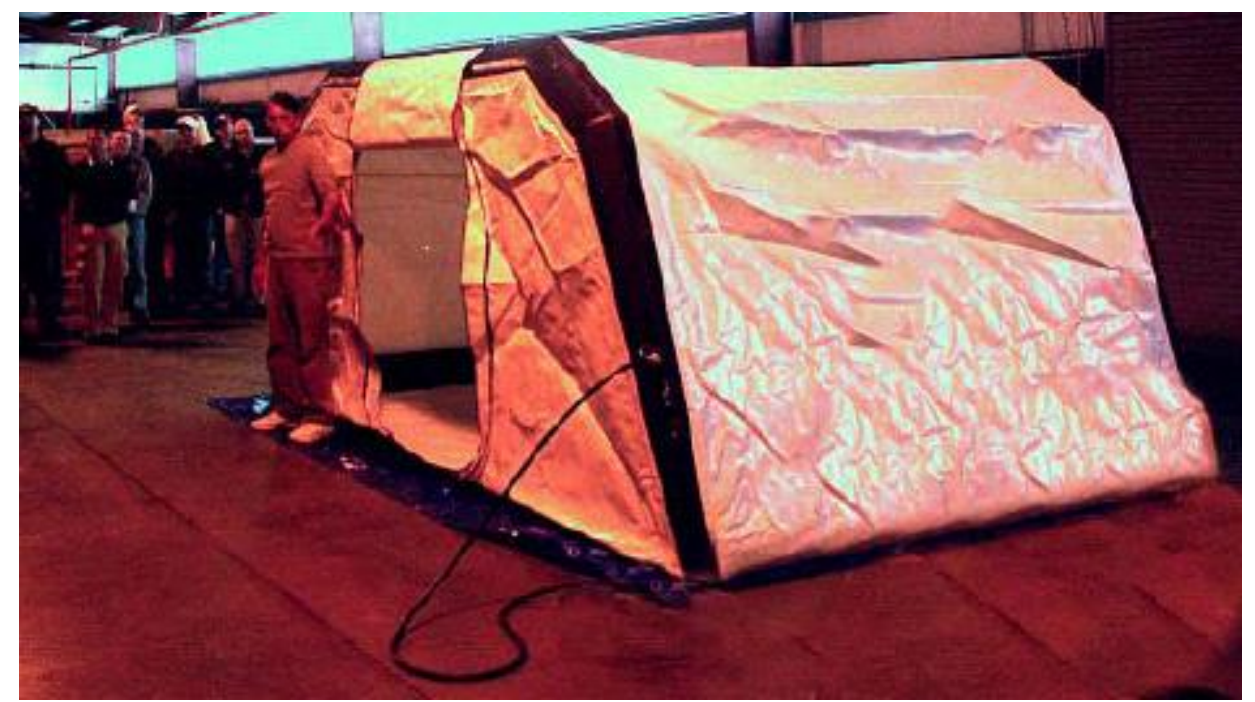

Figure 2-7. The LifeShelter by ChemBio Inc. (MSHA, 2006)

\subsubsection{Summary of Shelter Availability}

This is a brief introduction on the availability of underground coal mine refuge shelters and the companies that are currently building them. Each is designed in a different way, and some require power while others do not. In Appendix A-1 a list is provided to further evaluate each shelters abilities. 


\subsection{A Future Proposal To Support Underground Coal Mine Emergencies}

The Lifepod system is designed to accommodate miners after an emergency event in coal seams lower than 40 inches. The Lifepod design is to be used by miners in a specified crosscut and incorporates the usage of air curtains to form a shelter. After an emergency event miners will enter the specified crosscut and will connect through a central air control system to individualized National Institute of Occupational Safety and Health (NIOSH) certified, Occupational Safety and Health Administration (OSHA) compliant full face SCBA mask which is shown in Figure 2-8. Each miner will have an individual air line of 25 to 30 feet in length and the air lines will connect directly to a central air control panel. The miners will then deploy the air curtains to form an enclosed shelter.

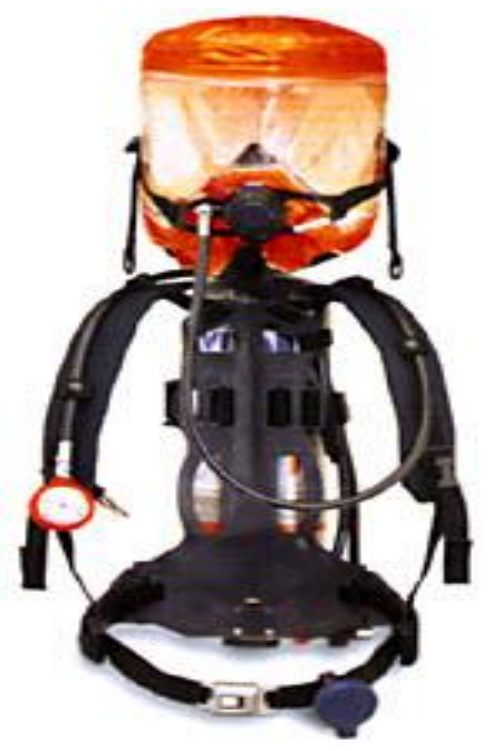

Figure 2-8 Survivair Puma SCBA mask 
There are two types of the Lifepod system available, one is the Standard LS/28 and is a low pedestal shelter that will be used in coal seams lower than 40 inches. The other is the Lifepod Emergency Shelter LS/18 and can accommodate coal mines under 30 inches in height.

\subsection{The Shelters Approved in the state of West Virginia}

The Aracoma and Sago disasters along with the fourteen deaths that took place during January, 2006 brought to the forefront the need for improvements in emergency equipment, capabilities and processes. As a result of these two mining incidents and the global attention they received, the public's view of underground coal mining has been drastically shifted.

Throughout the history of coal mining in West Virginia and the entire U. S. many regulations have been adopted time after time and usually take place after tragic events such as those that occurred at Aracoma and Sago. These new laws are normally focused on improving mine safety, emergency equipment, and mining processes in order to reduce the possibility of fatalities after an emergency event. This is accomplished through diligent and enduring work by legislative bodies not only in West Virginia but throughout the U.S. This effort has helped create a better working environment for underground coal miners while keeping the impact on nationwide coal production to a minimum.

After the Aracoma and Sago disasters West Virginia moved quickly to improve its mining processes and equipment laws. With the urging of the state governor at the time, lawmakers passed a bill on January 23,2006 , that will require coal mine operators to use electronic devices to track trapped miners and stockpile oxygen to keep them alive until help arrives. Upon the passing of this bill, coal companies had until the end of 
February 2006 to meet the new requirements or they would be subject to penalties such as fines or even mine closure (MSNBC, 2006).

The law making did not stop there in West Virginia as lawmakers went on to adopt another equipment related law that added to a long list of emergency equipment already required for use in underground coal mines. On March 9th, 2007, the WVOMHST approved the refuge shelters made by five manufacturers of underground coal refuge shelters for use in West Virginia's underground coal mines (WVOMHST, 2007). The five companies and their products that were approved are the following:

\section{Kennedy Metal Products, Inc.}

The Kennedy Chamber which is a hard-walled shelter that can be scaled to size for 10-33 miners and provides 96-hours of life support for the chosen capacity.

\section{ChemBio Shelter, Inc.}

The LifeShelter is an inflatable soft-walled shelter that can be scaled in order to accommodate from 10-30 miners and provides 96-hours of life support for the chosen capacity.

\section{Draeger Safety Inc.}

The Draeger Emergency Shelter is a hard-walled shelter that comes in 10 and 16 miner models and provides 96-hours of life support for the chosen capacity

\section{Strata Products (USA), Inc.}

The Fresh Air Bay which is an inflatable soft-walled shelter that comes in models for 10,16 , or 20 miners and provides 96 -hours of life support for the chosen capacity.

The Coal Mine Refuge Chamber is a hard-walled shelter that comes in models for 8,16 , or 20 miners and provides 96-hurs of life support for the chosen capacity. 


\subsection{Summary}

This chapter is about the first manufacturers of underground coal refuge shelters in the U.S. and the ones that were approved by the state of West Virginia. The door has been left open for other companies to apply for approval of their product if they can pass state and federal guidelines.

The approval of these underground shelters was a significant step toward improving underground coal mine safety in West Virginia and possibly other states as some are expected to adopt similar laws requiring shelters in their underground coal mines. This new law is expected to have a huge impact on post emergency safety because it provides a way for miners to sustain life if all passages are cutoff after an emergency event.

Upon approval of these shelters, mine operators had a time frame that lasted until April 15, 2007 to submit their shelter plans that included their choice of shelter to the WV Office of Miners' Health, Safety and Training office. One of the criteria they must meet is to locate one shelter within 1000 feet of a working face in a crosscut against the in-by rib. It is estimated that the shelters will be moved about once a week and that over a shelters 10 year life expectancy, being moved once a week will equate to it being moved over 500 times and will travel up to 95 miles within a mine. A list of all the state requirements regarding underground refuge shelters is provided in Appendix A-2. 


\section{Chapter 3}

\section{Structural Analysis of Shelters}

This chapter focuses on the structural evaluation of both types of shelters available, hard-walled and soft-walled. The structural requirements for the shelters promulgated by Mine Safety and Health Administration (MSHA) and the West Virginia Office of Miners Health, Safety and Training (WVOMHST) will be investigated.

\subsection{Structural Analysis of Hard-Walled Shelters}

The hard-walled shelters are designed for a 96-hour (four days) duration to support miners who are not able to escape right after an emergency event in an underground coal mine. The exterior appearance of hard-walled shelters is a steel surface with one window and one door. The door is typically attached to the frame with three or more hinges to optimize structural integrity, depending on the design made by the individual manufacturer. The windows are typically made of super abrasion resistant (SAR) acrylic sheets. An analysis of the outer surface, skeleton, doors and windows are provided.

The outer surface of the hard-walled shelters is designed with a steel sheet and steel beam skeleton configuration. The support for the outer surface is constructed of a steel tubing structure while the outside surface is basically made of steel sheets mounted onto the steel beam structure. This steel tube frame structure is the same for the roof, walls and floor except that the dimensions for the beams in each section vary slightly. They are arranged to form a hoop like structure that allows them to transmit stress 
directly between one another more easily. The sidewall skeleton beams are connected to the roof using 45-degree connectors. A schematic diagram of the outer surface can be seen in Figure 3-1.

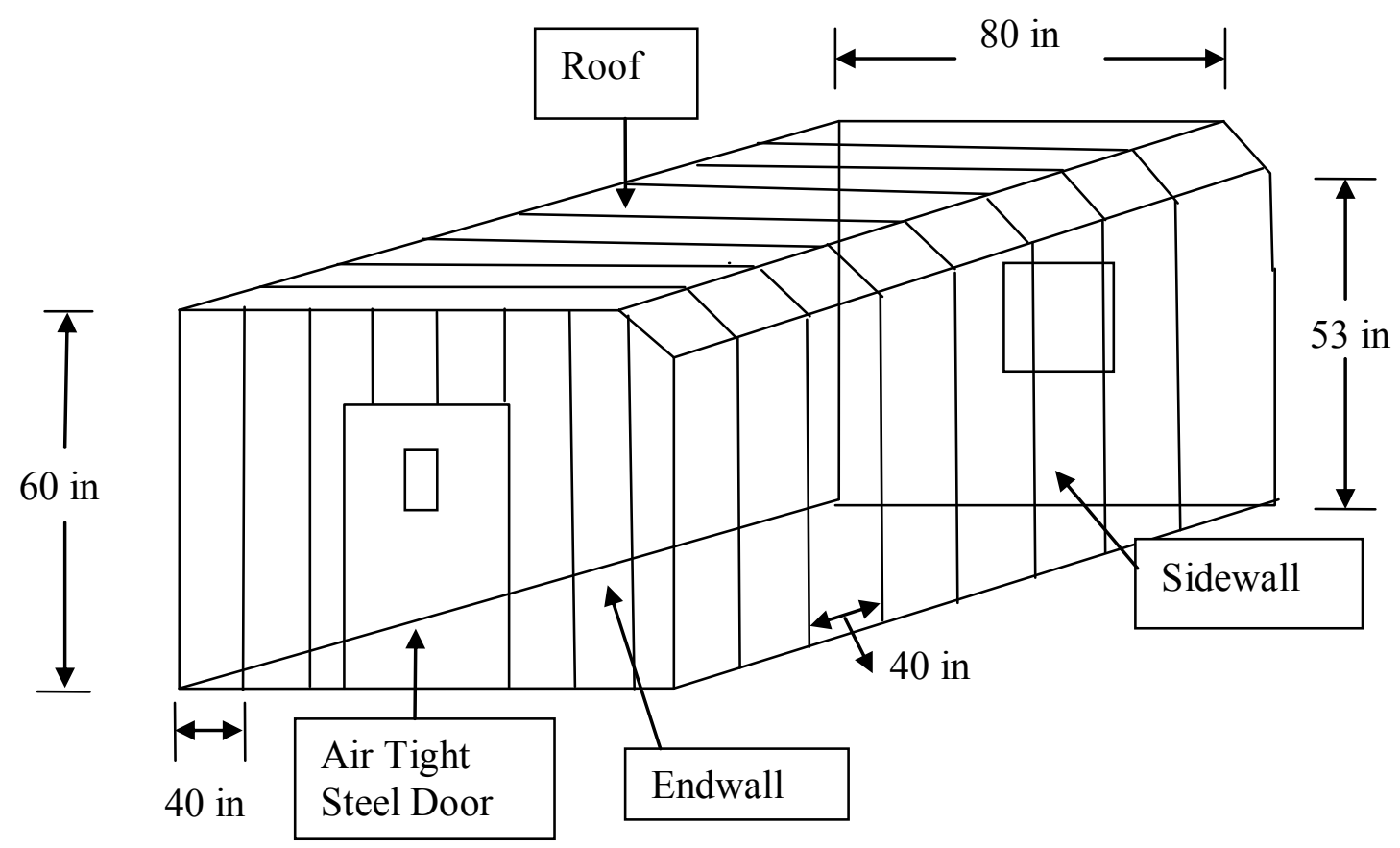

Figure 3-1. Schematic of a Hard-Walled Shelter

\subsubsection{Analysis of Steel Beam Structure in Hard-walled Shelters}

The overpressure requirements set forth for structural integrity of emergency shelters are the same from both WVOMHST and MSHA. Each require an approved shelter being used in an underground coal mine to be capable of withstanding a 15 psi constant overpressure for 3 seconds. To determine if the steel beams meet this requirement a common stress formula used by the American Institute of Steel Construction (AISC) can be used. The formulas from this section can be used to 
determine the bending moment (moment in which an object begins to bend) of a beam. The result is used to evaluate a steel shelters performance when a 15 psi overpressure is applied.

In this analysis of the steel beam skeleton structure where the tubing is covered by steel sheets, the sheets are not considered in these structural calculations and their ability to withstand a 15 psi overpressure will be considered later in this chapter. The beams are only considered in these calculations and assume simply supported beam members with uniformly distributed loads.

The formula for the maximum bending moment, $M_{\max }$, through the centroid of one of the steel tubing beams is:

$$
\mathrm{M}_{\max }=\frac{(\mathrm{W} \cdot \mathrm{L})}{\mathrm{D}}
$$

Where:

$\mathrm{M}_{\max }=$ maximum bending moment through the centroid, in-lbs

$\mathrm{W}=$ total distributed load that is imposed on a simply supported beam member, lbs

$\mathrm{L}=$ length of a particular member, inches

$\mathrm{D}=8$ for a simply loaded beam, (AISC, 1989)

A load that is imposed on a beam member, $\mathrm{W}$, is calculated by:

$$
\mathrm{W}=(\mathrm{L} \cdot \mathrm{Dist} \cdot \mathrm{P})
$$

Where:

Dist. $=$ spacing between beams, inches

$\mathrm{P}=$ applied pressure, psi. 
Using the results from Eqs. (3-1) and (3-2), the extreme fiber stress generated in a particular beam can be calculated by the following equation:

$$
\mathrm{f}=\left(\frac{\mathrm{M}_{\max }}{\mathrm{S}}\right)
$$

Where:

$\mathrm{f}=$ extreme fiber stress in a beam, psi

$\mathrm{M}_{\max }=$ maximum bending moment through the centroid, in-lbs

$\mathrm{S}=$ section modulus of the beam on an axis, in $^{3}$ (AISC, 1989)

By knowing extreme fiber stress $\mathrm{f}$, the result can be used to determine if the steel beams being used are strong enough to meet WVOMHST and MSHA requirements of a 15 psi overpressure. The steel yield rating value can be found in the book by the American Institute of Steel Construction, Inc. for a particular grade of steel (See Appendix B-2). The value is then divided by the extreme fiber stress, f. If the safety factor is 1 or above then this means the steel being used will withstand the 15 psi overpressure. The expression to determine the safety factor is shown below.

$$
\text { Safety Factor }=\frac{\text { AISC Steel Rating }}{\text { extreme fiber stress, } \mathrm{f}}
$$

The safety factor test can be used to determine if the design of the hard-walled shelters meet MSHA and WVOMHST requirements when a 15 psi overpressure is applied. The type of steel that is being used in a typical hard-walled shelter is the A50. The ASTM designated yield strength of A50 steel is 50,000 psi (See Appendix B-2). So if a steel beam in a hard-walled shelter had an extreme fiber stress of 50,000 psi, using 
Eq. (3-4) will give a safety factor of 1.0, which means the grade of steel that is being used would be safe to use in order to meet the 15-psi rating. The higher the safety factor the easier the steel will withstand a certain pressure or load, in this case a $15 \mathrm{psi}$ overpressure.

\subsubsection{Roof Beam Structure Analysis of Hard-walled Shelters}

For a roof steel tube beam member for an $8 \mathrm{ft}$ wide shelter, the roof section of the skeleton structure is coupled on each end with two sidewall to roof diagonal members, which are set at 45 degrees on each end. The length of the roof tube that comes under investigation in this example is then reduced to only $6.66 \mathrm{ft}$ ( $80 \mathrm{in}$ ) long. This was determined using the following trigonometric tangent function shown with Eq. (3-5).

$$
\tan \theta=\frac{\text { length of opposite side }}{\text { length of adjacent side }}
$$

Figure 3-2 shows that a right triangle can be formed on both sides of the roof. Using Eq. (3-5) the calculation of the length of the adjacent side of the right triangles formed in the roof can be determined. Once this is determined it can be subtracted from the width of the shelters at the base. This will give the length of the roof beams when connected to 45 degree connectors.

$$
\tan (45)=\frac{7 \text { in }}{\text { length adjacent side }}
$$

Rearranging terms makes it:

$$
\text { length adjacent side }=\frac{7 \text { in }}{\tan \left(45^{\circ}\right)}=7 \text { in }
$$


Since the width of the base is equal to 94 inches and subtracting 7 in from both sides for each of the two right triangles yields the length of the roof beams that need to be analyzed.

$$
94 \text { in }-7 \text { in }-7 \text { in }=80 \text { in (lenth of the roof beams) }
$$

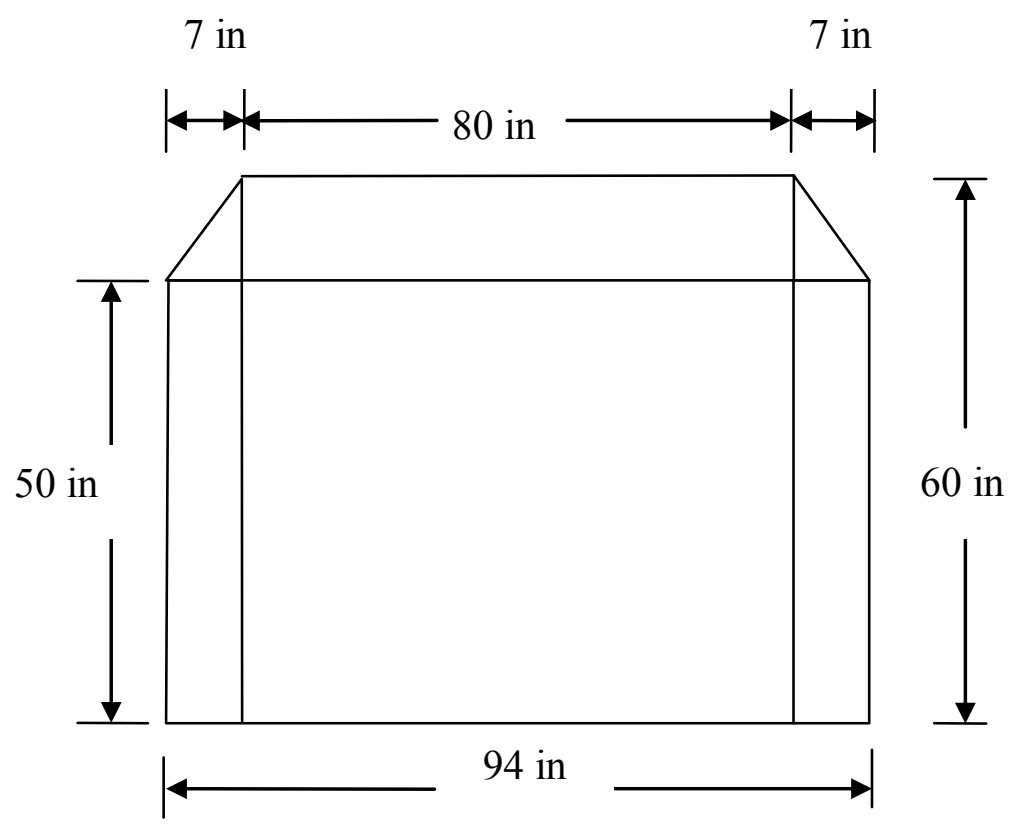

Figure 3-2. Dimensions of Underground Shelters

When a 15 psi overpressure is applied to a beam in the roof the outcome is a maximum bending moment, $\mathrm{M}_{\max }$, of 168,000 in-lbs using Eq. (3-1) and a load, $\mathrm{W}$, of 16,800 lbs using Eq. (3-2) that is imposed on each roof beam member when spaced 14inches apart. The tube cross sectional size that is typically used in the roof of the metal shelters is 6 in. $\mathrm{H} \times 3$ in. $\mathrm{W} \times 3 / 8$ in. T. The roof beams are utilized on their $\mathrm{y}$-axis (See Figure 3-3), thus yielding a $5.19 \mathrm{in}^{3}$ section modulus, $\mathrm{S}$, and a moment of inertia, I, of $7.51 \mathrm{in}^{4}$, both of which are properties of the beams resistance to bending. It is important to remember that the section modulus and moment of inertia are properties of the cross 
sectional area of the steel rectangular tubing beams on an axis and the yield strength is a property depending on the steel type (AISC, 1989).

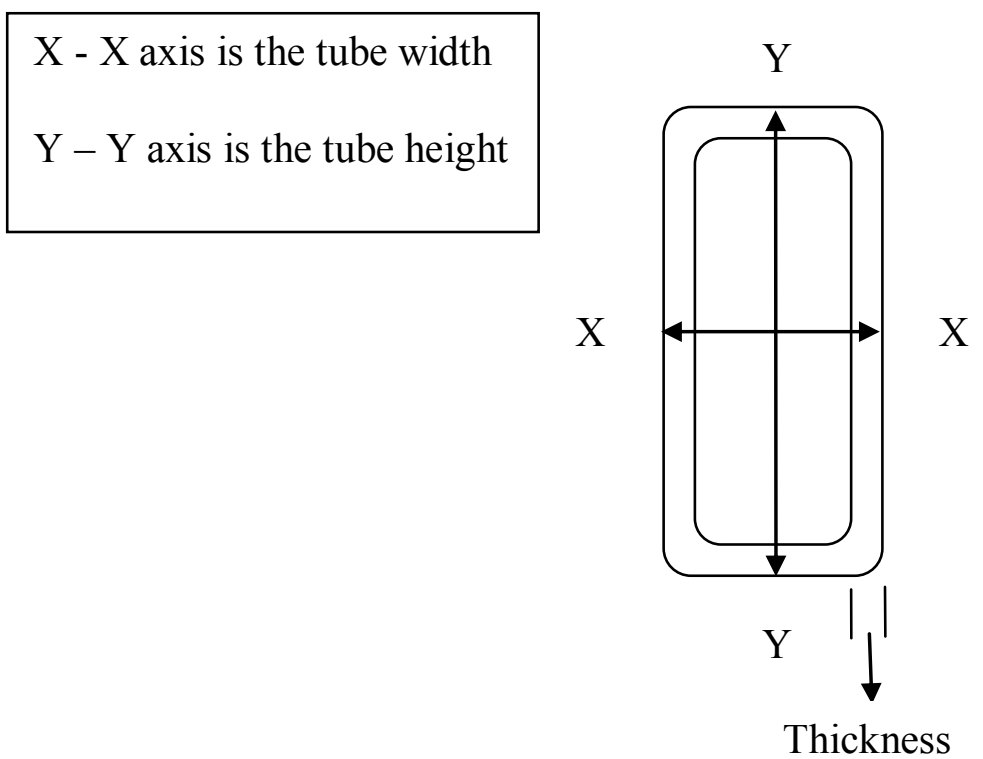

Figure 3-3 Cross section view of tubing beams.

Using the results from Eq. (3-1) and Eq. (3-2) gives a 32,370 psi maximum fiber stress, $\mathrm{f}$, that would be imposed on the roof beams when a 15 psi overpressure is applied and was determined using Eq. (3-3). This is well within the required maximum working range of 50,000 psi yield strength for this particular size of A50 type steel structural tube. The safety factor for the roof is 1.54 as determined from Eq. (3-4). See Tables 3.1 and 3.2 for the results as the calculations are carried out (AISC, 1989). 
Table 3.1 Dimensions and Properties of Steel Rectangular Beams in the Roof.

\begin{tabular}{|c|c|c|c|c|c|c|c|}
\hline \multicolumn{7}{|c|}{ Steel Tubing Dimensions and Properties } \\
\hline X-Sec & $\begin{array}{c}\text { Height } \mathrm{H} \\
\text { (in) }\end{array}$ & $\begin{array}{c}\text { Width } \mathrm{W} \\
\text { (in) }\end{array}$ & $\begin{array}{c}\text { Thickness } \\
\mathrm{T} \text { (in) }\end{array}$ & $\begin{array}{c}\text { Steel } \\
\text { Type }\end{array}$ & $\begin{array}{c}\text { Yield } \\
\text { Strength } \\
(\mathrm{psi})\end{array}$ & $\begin{array}{c}\text { Moment of } \\
\text { Inertia I } \\
\left(\mathrm{in}^{4}\right)\end{array}$ & $\begin{array}{c}\text { Section } \\
\text { Modulus } \\
\mathrm{S}^{\left(\mathrm{in}^{3}\right)}\end{array}$ \\
\hline Tube & 6.00 & 3.0 & 0.375 & $\mathrm{~A} 50$ & 50,000 & 7.78 & 5.19 \\
\hline
\end{tabular}

Table 3.2 Stress Formula Outputs of Beams in the Roof.

\begin{tabular}{|c|c|c|c|c|c|c|}
\hline \multicolumn{7}{|c|}{ Steel Tubing Stress Outputs } \\
\hline $\begin{array}{c}\text { Span L } \\
\text { (in) }\end{array}$ & $\begin{array}{c}\text { Spacing S } \\
\text { (in) }\end{array}$ & $\begin{array}{c}\text { Pressure P } \\
\text { (psi) }\end{array}$ & $\begin{array}{c}\text { Total } \\
\text { Loading } \\
\text { W (lb) }\end{array}$ & $\begin{array}{c}\text { Maximum } \\
\text { Bending } \\
\text { Moment } \\
\text { M (in-lb) }\end{array}$ & $\begin{array}{c}\text { Extreme Fiber } \\
\text { Stress } \\
\text { f (psi) }\end{array}$ & $\begin{array}{c}\text { Factor of } \\
\text { Safety }\end{array}$ \\
\hline 80.0 & 14 & 15 & 16,800 & 168,000 & 32,370 & 1.54 \\
\hline
\end{tabular}

$$
M=\frac{(\mathrm{W} \cdot 80 \mathrm{in})}{8}
$$

$$
\begin{aligned}
& \mathrm{W}=(80 \mathrm{in} \cdot 14 \mathrm{in} \cdot 15 \mathrm{psi})=16,800 \mathrm{lbs} \\
& \mathrm{M}=\frac{(16,80 \mathrm{lbs} \cdot 80 \mathrm{in})}{8}=168,000 \mathrm{in}-\mathrm{lbs}
\end{aligned}
$$

The maximum fiber stress that a 15 psi overpressure will supply can then be calculated using Eq. (3-3).

$$
\mathrm{f}=\frac{168,000 \mathrm{in}-\mathrm{lbs}}{5.19 \mathrm{in}^{3}}=32,370 \mathrm{psi}
$$

The yield range for this type of steel structural tubing is 50,000 psi. This is well within the safe working range. The safety factor is then calculated using Eq. (3-4) as shown below. 


$$
\text { Safety Factor }=\frac{50,000 \mathrm{psi}}{32,370 \mathrm{psi}}=1.54
$$

\subsubsection{Sidewall and End-Wall Structure Analysis of Hard-walled Shelters}

The sidewall and end-wall structures will also be designed using 14 in. spacing between the steel rectangular beams. The tube lengths will be 53 in. and 60 in.

respectively and will measure 6 in. $\mathrm{H} \times 3$ in. W x 3/16 in. T in both the end-wall and sidewall sections. These are slightly different dimensions than the roof tubes, but they are also utilized on their y-axis. The result of using different dimensions is that the section modulus and moment of inertia will change and they will now be $3.22 \mathrm{in}^{3}$ and $4.83 \mathrm{in}^{4}$, respectively. The resulting extreme fiber stresses will be 23,899 psi using Eq. (3-3) for the sidewalls and 29,348 psi for the end-walls, which is well below the yield loading of the A50 steel of 50,000 psi. The calculations are not carried out as they were for the roof, but their results are shown in Tables 3.3 and 3.4 for the sidewalls and Tables 3.5 and 3.6 for the end-walls (AISC, 1989).

In Tables 3.4 and 3.6 the safety factors are shown which are 2.18 and 1.70

for the sidewall and end-wall, respectively. This result shows that both are designed to easily withstand the 15 psi requirement. 
Table 3.3 Dimensions and Properties of Steel Rectangular Beams in the Sidewalls.

\begin{tabular}{|c|c|c|c|c|c|c|c|}
\hline \multicolumn{7}{|c|}{ Steel Tubing Dimensions and Properties } \\
\hline X-Sec & $\begin{array}{c}\text { Height H } \\
\text { (in) }\end{array}$ & $\begin{array}{c}\text { Width W } \\
\text { (in) }\end{array}$ & $\begin{array}{c}\text { Thickness } \\
\text { T (in) }\end{array}$ & $\begin{array}{c}\text { Steel } \\
\text { Grade }\end{array}$ & $\begin{array}{c}\text { Yield } \\
\text { Strength } \\
(\mathrm{psi})\end{array}$ & $\begin{array}{c}\text { Moment of } \\
\text { Inertia I } \\
\left(\text { in }^{4}\right)\end{array}$ & $\begin{array}{c}\text { Section } \\
\text { Modulus } \\
\text { S (in }{ }^{3}\end{array}$ \\
\hline Tube & 6.00 & 3.0 & 0.1875 & $\mathrm{~A} 50$ & 50,000 & 4.83 & 3.22 \\
\hline
\end{tabular}

Table 3.4 Stress Formula Outputs of Beams in the Sidewalls.

\begin{tabular}{|c|c|c|c|c|c|c|}
\hline \multicolumn{7}{|c|}{ Steel Tubing Stress Outputs } \\
\hline $\begin{array}{c}\text { Span L } \\
\text { (in) }\end{array}$ & $\begin{array}{c}\text { Spacing S } \\
\text { (in) }\end{array}$ & $\begin{array}{c}\text { Pressure P } \\
\text { (psi) }\end{array}$ & $\begin{array}{c}\text { Total } \\
\text { Loading } \\
\text { W (lb) }\end{array}$ & $\begin{array}{c}\text { Maximum } \\
\text { Bending } \\
\text { Moment } \\
\text { M (in-lb) }\end{array}$ & $\begin{array}{c}\text { Extreme Fiber } \\
\text { Stress } \\
\mathrm{f}(\mathrm{psi})\end{array}$ & $\begin{array}{c}\text { Factor of } \\
\text { Safety }\end{array}$ \\
\hline 53.0 & 14 & 15 & 11,130 & 73,736 & 22,899 & 2.18 \\
\hline
\end{tabular}

Table 3.5 Dimensions and Properties of Steel Rectangular Beams in the End-Walls.

\begin{tabular}{|c|c|c|c|c|c|c|c|}
\hline \multicolumn{7}{|c|}{ Steel Tubing Dimensions and Properties } \\
\hline X-Sec & $\begin{array}{c}\text { Height H } \\
\text { (in) }\end{array}$ & $\begin{array}{c}\text { Width } \mathrm{W} \\
\text { (in) }\end{array}$ & $\begin{array}{c}\text { Thickness } \\
\text { T (in) }\end{array}$ & $\begin{array}{c}\text { Steel } \\
\text { Grade }\end{array}$ & $\begin{array}{c}\text { Yield } \\
\text { Strength } \\
(\mathrm{psi})\end{array}$ & $\begin{array}{c}\text { Moment of } \\
\text { Inertia I } \\
\left(\mathrm{in}^{4}\right)\end{array}$ & $\begin{array}{c}\text { Section } \\
\text { Modulus } \\
\mathrm{S}^{\left(\mathrm{in}^{3}\right)}\end{array}$ \\
\hline Tube & 6.00 & 3.0 & 0.1875 & $\mathrm{~A} 50$ & 50,000 & 4.83 & 3.22 \\
\hline
\end{tabular}

Table 3.6 Stress Formula Outputs of Beams in the End-Walls.

\begin{tabular}{|c|c|c|c|c|c|c|}
\hline \multicolumn{7}{|c|}{ Steel Tubing Stress Outputs } \\
\hline $\begin{array}{c}\text { Span L } \\
\text { (in) }\end{array}$ & $\begin{array}{c}\text { Spacing S } \\
\text { (in) }\end{array}$ & $\begin{array}{c}\text { Pressure P } \\
\text { (psi) }\end{array}$ & $\begin{array}{c}\text { Total } \\
\text { Loading } \\
\text { W (lb) }\end{array}$ & $\begin{array}{c}\text { Maximum } \\
\text { Bending } \\
\text { Moment } \\
\text { M (in-lb) }\end{array}$ & $\begin{array}{c}\text { Extreme Fiber } \\
\text { Stress } \\
\mathrm{f}(\mathrm{psi})\end{array}$ & $\begin{array}{c}\text { Factor of } \\
\text { Safety }\end{array}$ \\
\hline 60.0 & 14 & 15 & 12,600 & 94,500 & 29,348 & 1.70 \\
\hline
\end{tabular}




\subsubsection{Floor Structure Analysis of Hard-Walled Shelters}

The floor structure will also be placed on 14 in. centers just like the side and roof sections and the floor tubing beams will also be utilized on their y-axis. The dimensions for the tubes placed in the floor are 6 in. $\mathrm{H} \times 4$ in. $\mathrm{W} \times 3 / 8$ in. T. These dimensions are different from those used elsewhere, and the result is a moment of inertia of $15.6 \mathrm{in}^{4}$ and a section modulus of $7.82 \mathrm{in}^{3}$. As in the results for the sidewall and end-wall, the calculations using the appropriate equations are provided in Tables (3.7) and (3.8) (AISC, 1989).

Table 3.7 Dimensions and Properties of Steel Rectangular Beams in the Floor.

\begin{tabular}{|c|c|c|c|c|c|c|c|}
\hline \multicolumn{7}{|c|}{ Steel Tubing Dimensions and Properties } \\
\hline X-Sec & $\begin{array}{c}\text { Height H } \\
\text { (in) }\end{array}$ & $\begin{array}{c}\text { Width W } \\
\text { (in) }\end{array}$ & $\begin{array}{c}\text { Thickness } \\
\text { T (in) }\end{array}$ & $\begin{array}{c}\text { Steel } \\
\text { Grade }\end{array}$ & $\begin{array}{c}\text { Yield } \\
\text { Strength } \\
\text { (psi) }\end{array}$ & $\begin{array}{c}\text { Moment of } \\
\text { Inertia I } \\
\left(\text { in }^{4}\right)\end{array}$ & $\begin{array}{c}\text { Section } \\
\text { Modulus } \\
\text { S (in }{ }^{3}\end{array}$ \\
\hline Tube & 6.00 & 3.0 & 0.375 & A50 & 50,000 & 15.6 & 7.82 \\
\hline
\end{tabular}

Table 3.8 Stress Formula Outputs of Beams in the Floor.

\begin{tabular}{|c|c|c|c|c|c|c|}
\hline \multicolumn{7}{|c|}{ Steel Tubing Stress Outputs } \\
\hline $\begin{array}{c}\text { Span L } \\
\text { (in) }\end{array}$ & $\begin{array}{c}\text { Spacing } \\
\text { S } \\
\text { (in) }\end{array}$ & $\begin{array}{c}\text { Pressure P } \\
\text { (psi) }\end{array}$ & $\begin{array}{c}\text { Total } \\
\text { Loading } \\
\text { W (lb) }\end{array}$ & $\begin{array}{c}\text { Maximum } \\
\text { Bending } \\
\text { Moment } \\
\text { M (in-lb) }\end{array}$ & $\begin{array}{c}\text { Extreme Fiber } \\
\text { Stress } \\
\mathrm{f}(\mathrm{psi})\end{array}$ & $\begin{array}{c}\text { Factor of } \\
\text { Safety }\end{array}$ \\
\hline 94.0 & 14 & 15 & 19,740 & 231,945 & 29,660 & 1.69 \\
\hline
\end{tabular}

The end result in the design of the floor structure is a 39,660 maximum fiber stress when a 15-psi pressure is applied. The AISC yield strength rating is 50,000 psi which is the same for all steel beams being used in a typical hard-walled steel structure. This gives a safety factor of 1.69 which shows the floor structure could withstand a 15psi overpressure quiet well. It is important to remember that in most cases the floor will 
be placed on the ground and would not even be subjected to an overpressure from an explosion. The results are provided for the case in which the floor might be subjected to an explosion.

\subsubsection{Steel Sheet Analysis of Hard-Walled Shelters}

The greatest unsupported span for the metal sheets that make up the outer surface is $8 \mathrm{in}$. The steel sheets, sometimes referred to as plates, can be investigated as simply supported flat plates with an $8 \mathrm{in}$. span and a $4 \mathrm{in}$. width that is loaded with a pressure of 15 psi. The standard formula for flat plates with simply supported straight boundaries on two opposite edges can be found in Roark's Formulas for Stress and Strain (Roark, 1982). Using Eq. (3-6) shows what the deformation of the steel sheets will be when a 15 psi overpressure is applied.

$$
\max y=\frac{\left(\alpha \cdot q \cdot b^{4}\right)}{\left(E \cdot t^{3}\right)}
$$

Where:

max $y=$ maximum deflection or bending, inches $\alpha=\mathrm{a}$ factor from case $15 \mathrm{a}$, Table 26 , article 10.10 that is related to the ratio of the length of the sides of the plate under investigation (2:1 in this case) and is equal to 2.58 (See Appendix B-3),

$\mathrm{E}=$ the materials modulus of elasticity which is $29 \times 10^{6}$ for steel sheets, psi

$\mathrm{q}=$ applied overpressure, $\mathrm{psi}$

$\mathrm{b}=$ length of the shortest side, inches

$\mathrm{t}=$ thickness of steel plate, inches 


$$
\max y=\frac{\left(2.58 \cdot 15 \mathrm{psi} \cdot 4^{4} \mathrm{in}\right)}{\left(29,000,000 \mathrm{psi} \cdot 0.097^{3} \mathrm{in}\right)}=0.3743 \mathrm{in}
$$

When applying Eq. (3-6) to the given parameters the result shows that the maximum deflection that would occur when a 15 psi over pressure is applied to the steel

plates having a modulus of elasticity of $29 \times 10^{6} \mathrm{psi}$ is only $0.3743 \mathrm{in}$. This small amount would result in minimal damage to the steel shelter, therefore meeting the WVOMHST and MSHA 15 psi overpressure requirement.

\subsubsection{Steel Door Analysis of Hard-Walled Shelters}

The design on the door of the steel chambers is a steel sheet formed with stiffened flanges and reinforcing tubes that are applied to the outside of the steel door. The greatest spacing of the horizontal door tubes is 13 in. To limit the stress in the sheet, transverse $3 / 8$ in. W $x 1$ in. T rectangular bars are placed on 5 in. centers between the tubes, creating a much stronger door as shown in Figure 3-4. 


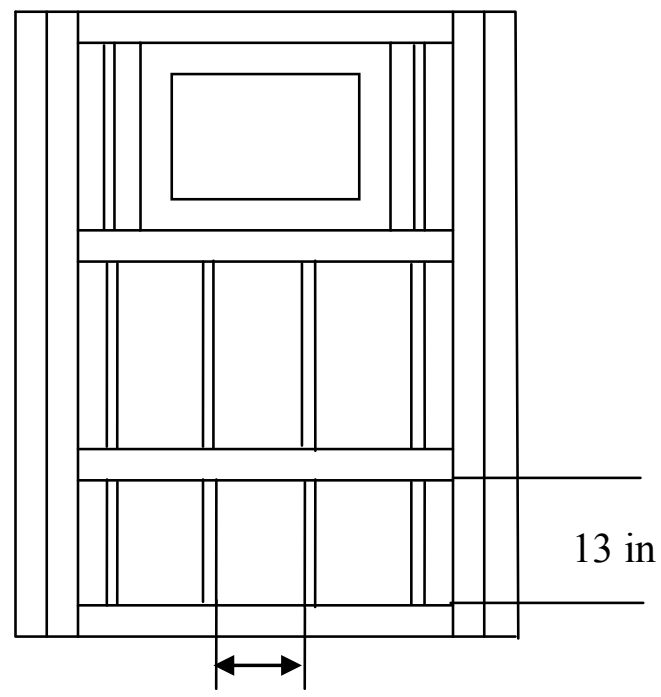

5 in

Figure 3-4. Steel Shelter Door Diagram.

The greatest spacing of the horizontal tubes is 13 inches and the number of tubes in the door depends on the height requested from a consumer. To limit the stress in the door, transverse $3 / 8$ in. $\mathrm{W} \times 1$ in. T rectangular bars are placed vertically 5 inches apart between the steel tubes. The upper and lower tubes shown in the drawing have support from the perimeter of the door opening and therefore are considered part of the end-wall. The tubes that need to be considered now are the ones placed in the center. Since they also are made of A50 steel they have a yield loading of 50,000 psi and with the support of the beams alone the door can easily withstand a 15 psi overpressure. The safety factor of the door 36.29 and this is shown with other parameters in Tables 3.9 and 3.10 (AISC, 1989). 
Table 3.9 Dimensions and Properties of Steel Rectangular Beams in the Door.

\begin{tabular}{|c|c|c|c|c|c|c|c|}
\hline \multicolumn{7}{|c|}{ Steel Tubing Dimensions and Properties } \\
\hline X-Sec & $\begin{array}{c}\text { Height } \mathrm{H} \\
\text { (in) }\end{array}$ & $\begin{array}{c}\text { Width W } \\
\text { (in) }\end{array}$ & $\begin{array}{c}\text { Thickness } \\
\mathrm{T} \text { (in) }\end{array}$ & $\begin{array}{c}\text { Steel } \\
\text { Grade }\end{array}$ & $\begin{array}{c}\text { Yield } \\
\text { Strength } \\
(\mathrm{psi})\end{array}$ & $\begin{array}{c}\text { Moment of } \\
\text { Inertia I } \\
\left(\text { in }^{4}\right)\end{array}$ & $\begin{array}{c}\text { Section } \\
\text { Modulus } \\
\mathrm{S}^{\left(\text {in }^{3}\right.}\end{array}$ \\
\hline Tube & 6.00 & 3.0 & 0.1875 & $\mathrm{~A} 50$ & 50,000 & 4.83 & 3.22 \\
\hline
\end{tabular}

Table 3.10 Stress Formula Outputs of Beams in the Door.

\begin{tabular}{|c|c|c|c|c|c|c|}
\hline \multicolumn{7}{|c|}{ Steel Tubing Stress Outputs } \\
\hline $\begin{array}{c}\text { Span - L } \\
\text { (in) }\end{array}$ & $\begin{array}{c}\text { Spacing } \\
\text { (in) }\end{array}$ & $\begin{array}{c}\text { Pressure } \\
\text { (psi) }\end{array}$ & $\begin{array}{c}\text { Total } \\
\text { Loading- } \\
\text { W (lb) }\end{array}$ & $\begin{array}{c}\text { Maximum } \\
\text { Moment - } \\
\text { M (in-lb) }\end{array}$ & $\begin{array}{c}\text { Extreme } \\
\text { Fiber Stress } \\
\mathrm{f}=\mathrm{M} / \mathrm{S} \\
(\mathrm{psi})\end{array}$ & $\begin{array}{c}\text { Factor of } \\
\text { Safety }\end{array}$ \\
\hline 13.0 & 14 & 15 & 2,730 & 4,436 & 1,378 & 32.69 \\
\hline
\end{tabular}

\subsubsection{Hard-Walled Shelter Window Analysis}

The type of glass being used in the shelters will be made of SAR acrylic sheets. It has been determined that the best material for window construction is SAR acrylic sheets which was chosen over tempered glass. The SAR was chosen over tempered glass because of the failure characteristics of tempered glass therefore making it a less viable candidate to be used in the shelters. The SAR is a heavy glass and was determined to be the best for the shelter application due to its durability. Another important feature is that it has a special coating that renders it very scratch resistant.

The largest window size lying between the beam members in the skeleton construction of the shelter is 8 in. wide. An 8 in. $\mathrm{W} \times 12$ in. $\mathrm{H} \mathrm{x} 1 / 2$ in. T window has been selected for use in the steel shelters. The yield strength of this particular of SAR is 10,000 psi according to the American Society for Testing Materials (ASTM) D638-03. Applying the same approach previously used on the windows being placed in the shelters shows in 
Table 3.12 the safety factor is 14.17 . This shows that the window could easily withstand a 15 psi overpressure from an explosion.

Table 3.11 Dimensions and Properties of the Windows.

\begin{tabular}{|c|c|c|c|c|c|c|c|}
\hline \multicolumn{7}{|c|}{ WIndow Dimensions and Properties } \\
\hline X-Sec & $\begin{array}{c}\text { Height H } \\
\text { (in) }\end{array}$ & $\begin{array}{c}\text { Width W } \\
\text { (in) }\end{array}$ & $\begin{array}{c}\text { Thickness } \\
\text { T (in) }\end{array}$ & $\begin{array}{c}\text { Window } \\
\text { Type }\end{array}$ & $\begin{array}{c}\text { Yield } \\
\text { Strength } \\
(\mathrm{psi})\end{array}$ & $\begin{array}{c}\text { Moment of } \\
\text { Inertia I } \\
\left(\text { in }^{4}\right)\end{array}$ & $\begin{array}{c}\text { Section } \\
\text { Modulus } \\
\text { S (in }{ }^{3}\end{array}$ \\
\hline Tube & 8.00 & 12.0 & 0.5 & SAR & 10,000 & 4.83 & 0.17 \\
\hline
\end{tabular}

Table 3.12 Stress Formula Outputs for the Window.

\begin{tabular}{|c|c|c|c|c|c|c|}
\hline \multicolumn{7}{|c|}{ Steel Tubing Stress Outputs } \\
\hline $\begin{array}{c}\text { Span L } \\
\text { (in) }\end{array}$ & $\begin{array}{c}\text { Spacing S } \\
\text { (in) }\end{array}$ & $\begin{array}{c}\text { Pressure P } \\
\text { (psi) }\end{array}$ & $\begin{array}{c}\text { Total } \\
\text { Loading } \\
\text { W (lb) }\end{array}$ & $\begin{array}{c}\text { Maximum } \\
\text { Bending } \\
\text { Moment } \\
\text { M (in-lb) }\end{array}$ & $\begin{array}{c}\text { Extreme Fiber } \\
\text { Stress } \\
\text { f (psi) }\end{array}$ & $\begin{array}{c}\text { Factor of } \\
\text { Safety }\end{array}$ \\
\hline 8.0 & 1 & 15 & 120 & 120 & 706 & 14.17 \\
\hline
\end{tabular}

\subsection{Structure Analysis of Soft-Walled Shelters}

The soft-walled shelters are a portable, fire retardant, nylon based structure that is stored inside a steel container that is explosion resistant called a skid container. In the case of an underground coal mine emergency, miners are required to locate the skid and open its steel door on one end to expose the soft-walled shelter. Once exposed the miners must open the valves of the compressed air cylinders and wait as the shelter inflates itself. The rugged, compactly stored, shelter membrane quickly opens using air beam technology to form an impermeable, hermetically sealed enclosure.

The soft-walled shelters are not designed to meet the WVOMHST and MSHA requirement of withstanding a 15 psi overpressure, but the steel skid container they are 
placed in is designed to meet this specification. This is because the soft-walled shelters will be located inside of the steel skid container during an initial explosion. To determine if the steel skid meets the requirement of a 15 psi overpressure the same techniques used in previous sections for steel beams and steel sheets of the hard-walled shelters can be used.

The design of the steel skid box is similar to the design of the hard-walled shelters except that the skid box is smaller. The type of steel being used in the steel skid will be of the same type that was used in the beams for the hard-walled shelters which was the A50 grade of steel. Just as in the hard-walled shelters, there will be steel sheets covering the outer surface that will be supported with square steel tubing beams. The cross section dimensions of these steel tubing beams will be 6 in. $\mathrm{H} \times 3$ in. $\mathrm{W} \times 3 / 8$ in. T throughout the steel skid container and just as in the hard-walled shelters the A50 steel has a yield strength of 50,000 psi. A diagram of each side of a typical steel skid container is provided in Figures 3-5 and 3-6.

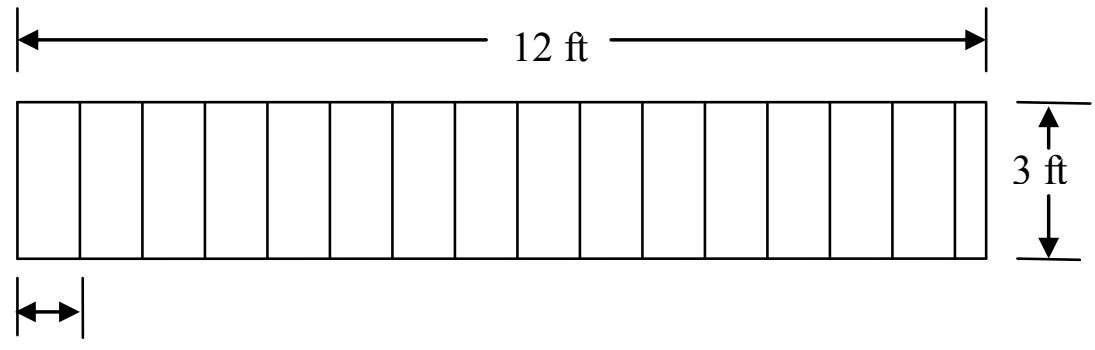

40 in

Figure 3-5 Sidewall view of Steel Skid Container 


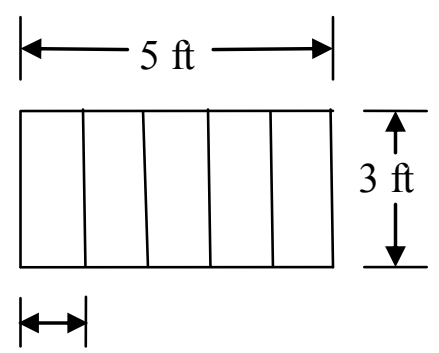

40 in

Figure 3-6 Endwall view of Steel Skid Container

\subsubsection{Beam Structure Analysis of Steel Skid Container Roof and Floor}

The rectangular beams used in the roof and floor of the steel skid container will be 60 in. long and the cross section will be 6 in. $\mathrm{H} \times 3$ in. $\mathrm{W} \times 3 / 8$ in. T. The beams will be utilized on their y-axis and will be placed 14-inches apart. This will give the beams in the roof and floor a $5.19 \mathrm{in}^{3}$ section modulus, $\mathrm{S}$, and a moment of inertia, I, of $7.51 \mathrm{in}^{4}$. The total loading on the beams when a 15 psi overpressure is applied to them will be 12,600 $\mathrm{lbs}$ as calculated with Eq. (3-2). The determination of the maximum bending moment can be shown using Eq. (3-1) and in this case is equal to 94,000 in-lbs. Using Eq. (3-3) shows that the extreme fiber stress generated on a beam in the roof and floor would be 12,583 psi. The safety factor will be 3.97 calculated with Eq. (3-4), and therefore, the beams in the roof and floor will easily withstand a 15 psi overpressure. It is important to remember that the beams in the floor in most cases would not be subjected to a 15 psi overpressure because it will be laying on the ground, but the results are presented for the case in which it may be. These are the same equations used for the analysis of the hard-walled shelters. The calculations will not be carried out again, but the results are provided in Tables 3.13 and 3.14 below (AISC, 1989). 
Table 3.13 Dimensions and properties of Steel Rectangular Tubes in the Roof and

Floor.

\begin{tabular}{|c|c|c|c|c|c|c|c|}
\hline \multicolumn{7}{|c|}{ Steel Tubing Dimensions and Properties } \\
\hline $\begin{array}{c}\text { X- } \\
\text { Sec }\end{array}$ & $\begin{array}{c}\text { Height H } \\
\text { (in) }\end{array}$ & $\begin{array}{c}\text { Width W } \\
\text { (in) }\end{array}$ & $\begin{array}{c}\text { Thickness } \\
\text { T (in) }\end{array}$ & $\begin{array}{c}\text { Steel } \\
\text { Type }\end{array}$ & $\begin{array}{c}\text { Yield } \\
\text { Strength } \\
(\mathrm{psi})\end{array}$ & $\begin{array}{c}\text { Moment of } \\
\text { Inertia I } \\
\left(\mathrm{in}^{4}\right)\end{array}$ & $\begin{array}{c}\text { Section } \\
\text { Modulus } \\
\mathrm{S}^{\left(\mathrm{in}^{3}\right)}\end{array}$ \\
\hline Tube & 6.00 & 3.0 & 0.375 & $\mathrm{~A} 50$ & 50,000 & 5.19 & 7.51 \\
\hline
\end{tabular}

Table 3.14 Stress Formula Outputs of Beams for the Roof and Floor.

\begin{tabular}{|c|c|c|c|c|c|c|}
\hline \multicolumn{7}{|c|}{ Steel Tubing Stress Outputs } \\
\hline $\begin{array}{l}\text { Span - L } \\
\text { (in) }\end{array}$ & $\begin{array}{l}\text { Spacing } \\
\text { (in) }\end{array}$ & $\begin{array}{l}\text { Pressure } \\
\quad(\mathrm{psi})\end{array}$ & $\begin{array}{c}\text { Total } \\
\text { Loading- } \\
\text { W (lb) }\end{array}$ & $\begin{array}{l}\text { Maximum } \\
\text { Moment - } \\
\text { M (in-lb) }\end{array}$ & $\begin{array}{c}\text { Extreme } \\
\text { Fiber Stress - } \\
\mathrm{f}=\mathrm{M} / \mathrm{S} \text { (psi) }\end{array}$ & $\begin{array}{c}\text { Factor of } \\
\text { Safety }\end{array}$ \\
\hline 60.0 & 14 & 15 & 12,600 & 94,500 & 12,583 & 3.97 \\
\hline
\end{tabular}

\subsubsection{Sidewall and End-Wall Structure Analysis of Steel Skid Container}

The same type of A50 rectangular steel beams will be used in the sidewalls and end-walls that are used on the roof and floor of the steel skid container. The height of the beams used in the sidewalls and end-walls will be 60 in. making them shorter than the ones used in the roof and floor. The cross section of the beams will have the same length, width, and thickness as the beams used in the roof and floor, so they will have the same section modulus and moment of inertia. The total loading on the beams when a $15 \mathrm{psi}$ overpressure is applied to them will be 6,300 lbs. as calculated with Eq. (3-2). The determination of the maximum bending moment can be shown using Eq. (3-1) and in this case is equal to 23,625 in-lbs. Using Eq. (3-3) shows that the extreme fiber stress generated from a 15 psi overpressure on a beam in the roof would be 3,146 psi. The 
safety factor will be 15.89 as determined with Eq. (3-4) and therefore easily withstanding a 15 psi overpressure. The results are shown in Tables 3.15 and 3.16 below.

Table 3.15 Dimensions and Properties of Steel Rectangular Tubes Used in the Sidewalls and End-Walls.

\begin{tabular}{|c|c|c|c|c|c|c|c|}
\hline \multicolumn{7}{|c|}{ Steel Tubing Dimensions and Properties } \\
\hline $\begin{array}{c}\mathrm{X}- \\
\text { Sec }\end{array}$ & $\begin{array}{c}\text { Height H } \\
\text { (in) }\end{array}$ & $\begin{array}{c}\text { Width W } \\
\text { (in) }\end{array}$ & $\begin{array}{c}\text { Thickness } \\
\text { T (in) }\end{array}$ & $\begin{array}{c}\text { Steel } \\
\text { Type }\end{array}$ & $\begin{array}{c}\text { Yield } \\
\text { Strength } \\
\text { (psi) }\end{array}$ & $\begin{array}{c}\text { Moment of } \\
\text { Inertia I } \\
\left(\text { in }^{4}\right)\end{array}$ & $\begin{array}{c}\text { Section } \\
\text { Modulus } \\
\left.\text { S (in }^{3}\right)\end{array}$ \\
\hline Tube & 6.00 & 3.0 & 0.375 & A50 & 50,000 & 5.19 & 7.51 \\
\hline
\end{tabular}

Table 3.16 Stress Formula Outputs of Beams for the Sidewalls and End-Walls.

\begin{tabular}{|c|c|c|c|c|c|c|}
\hline \multicolumn{7}{|c|}{ Steel Tubing Stress Outputs } \\
\hline Span - L (in) & $\begin{array}{c}\text { Spacing } \\
\text { (in) }\end{array}$ & $\begin{array}{c}\text { Pressure } \\
\text { (psi) }\end{array}$ & $\begin{array}{c}\text { Total } \\
\text { Loading- } \\
\text { W (lb) }\end{array}$ & $\begin{array}{c}\text { Maximum } \\
\text { Moment - } \\
\text { M (in-lb) }\end{array}$ & $\begin{array}{c}\text { Extreme } \\
\text { Fiber Stress - } \\
\text { f= M/S (psi) }\end{array}$ & $\begin{array}{c}\text { Factor of } \\
\text { Safety }\end{array}$ \\
\hline 30.0 & 14 & 15 & 6,300 & 23,625 & 3,146 & 15.89 \\
\hline
\end{tabular}

\subsubsection{Steel Sheet Analysis of Steel Skid Container}

The same approach used to analyze the surface of the hard-walled shelters can be used to analyze the surface of the steel skid container. The A50 type steel will also be used with the steel skid container. Just as on the surface of the hard-walled shelters, the greatest unsupported span for the metal sheets that make up the outer surface is $8 \mathrm{in}$. The steel sheets, sometimes referred to as plates, can be investigated as simply supported flat plates with an 8 in. span and a 4 in. width that will be loaded with a pressure of 15 psi. The standard formula for flat plates with simply supported straight boundaries on two opposite edges can be found in Roark's Formulas for Stress and Strain (Roark, 1982). 
Using Eq. (3-6) shows that the maximum deformation of the steel sheets will be 0.3743 in. when a 15 psi overpressure is applied.

$$
\max y=\frac{\left(2.58 \cdot 15 \mathrm{psi} \cdot 4^{4} \mathrm{in}\right)}{\left(29,000,000 \mathrm{psi} \cdot 0.097^{3} \mathrm{in}\right)}=0.3743 \mathrm{in}
$$

This small amount would result in very little damage to the steel skid container and would not harm the soft-walled shelter located inside. The result proves that the steel skid container meets both the WVOMHST and MSHA 15 psi overpressure requirement.

\subsection{Summary}

The WVOMHST and MSHA specifications require that an underground coal refuge shelter be capable of withstanding a 15 psi overpressure that may result from an explosion. The techniques used in this chapter are used to determine whether or not both the hard-walled and soft-walled shelters meet this requirement. After applying techniques used in the analysis of steel structures by the American Institute of Steel Construction (AISC) this chapter shows numerically how both the hard-walled and soft-walled shelters meet the 15 psi overpressure specifications. 


\section{CHAPTER 4}

\section{Air Quality Inside Shelters}

When there is an underground coal mine emergency in which miners are trapped in a confined area the quality and oxygen content of the air can decrease rapidly. This chapter will evaluate the underground coal refuge shelters capabilities to provide a breathable atmosphere for the inhabitants after an emergency event inside a coal mine, at which time they were unable to escape. The topics to be analyzed are the shelters abilities to provide minimum oxygen supplies and filter out life threatening gases such as carbon dioxide $\left(\mathrm{CO}_{2}\right)$ and carbon monoxide $(\mathrm{CO})$ in order to sustain life.

\subsection{MSHA Requirements for Providing Oxygen}

On June 15, 2006, The MINER ACT of 2006 became effective and Section 2 of the MINER ACT amends Section 316 of the Federal Mine Safety and Health Act of 1977. The amendment requires underground coal mine operators to develop and adopt within 60 days of enactment, a written emergency response plan (ERP) which is to be approved by MSHA. It also requires that the ERP provide a way for the evacuation of all miners endangered by an underground emergency event when possible and show the ability to support the lives of individuals trapped underground in the event that miners are not able to evacuate the mine. This act requires that all ERP's provide enough emergency supplies of breathable air for individuals that could be trapped underground sufficient to support their lives for a sustained period of time. 
The ERP's are to describe the operator's method for providing breathable air to trapped miners and to establish the locations designated for barricading (or other alternatives that will isolate the miners from contaminated environments) in which breathable air will be maintained. The locations of these areas should be shown on the escape map (MSHA, 2007).

In order to be included in an ERP, a refuge shelter must be able to supply and maintain a breathable atmosphere for miners. This has lead to how the air requirements will be met in the design of an underground coal refuge shelter. The shelters abilities to supply oxygen for each miner while diluting carbon dioxide $\left(\mathrm{CO}_{2}\right)$ and carbon monoxide (CO) are very important aspects that must be addressed in the design of underground coal refuge shelters.

\subsection{Oxygen Parameters}

The earth's atmosphere under normal conditions contains approximately 21 percent oxygen (See Table 4.1). When oxygen concentrations drop below 19.5 percent the atmosphere is considered oxygen deficient and adverse physiological effects begin to take place. The effects of an oxygen depleted atmosphere can be serious and lead to permanent central nervous system damage or even result in death depending on the time exposed to the oxygen depleted atmosphere and how low the oxygen concentration gets. When oxygen concentrations reach 17 percent or below, a human will begin breathing quicker and more deeply. As the oxygen concentrations continue to decline to 15 percent, a human will start to become dizzy, hear buzzing in the ears, and his/her heart will begin to beat rapidly. At 13 percent oxygen, humans will loose consciousness if exposed to this concentration for an extended period of time. As the oxygen concentration continues to 
drop in the atmosphere, death will result. The effects of an oxygen depleted atmosphere are shown in Table 4.2.

Table 4.1 Composition of Normal Air, (Hartman, 1997).

\begin{tabular}{|c|c|c|}
\hline Gas & Volume (\%) & Weight (\%) \\
\hline Nitrogen & 78.09 & 75.55 \\
\hline Oxygen & 20.95 & 23.13 \\
\hline Carbon Dioxide & 0.03 & 0.05 \\
\hline Argon, other rare gases & 0.93 & 1.27 \\
\hline
\end{tabular}

Table 4.2 The Effects of an Oxygen Depleted Atmosphere, (MSHA, 2007).

\begin{tabular}{||c|c||}
\hline Percent Oxygen in Air, \% & Effect \\
\hline \hline 17 & Faster, deep breathing \\
\hline \hline 15 & $\begin{array}{c}\text { Dizziness, buzzing in ears, rapid } \\
\text { heartbeat }\end{array}$ \\
\hline 13 & $\begin{array}{c}\text { May lose consciousness with } \\
\text { prolonged exposure }\end{array}$ \\
\hline \hline 9 & Fainting, unconsciousness \\
\hline \hline 7 & Life endangered \\
\hline \hline 6 & Convulsive movements, death \\
\hline \hline
\end{tabular}

In an effort to provide guidelines for supplying breathable air for coal miners after an emergency event, MSHA uses what is called the respiratory quotient, which is defined as the ratio of carbon dioxide expelled to oxygen consumed and MSHA has determined it to be 0.8 for coal mining. This is an average number since most technical sources site the 
number ranging from $0.7-1.0$ (MSHA, 2007). The respiratory quotient is used to calculate of carbon dioxide expelled per hour by each miner in a refuge shelter based on how much oxygen is consumed. The assumption that MSHA recommends is that when miners are trapped their activity levels will be at rest $4 / 5$ of the time and in moderate activity $1 / 5$ of the time. While at rest MSHA states that an average miner's breathing rate of $\mathrm{O}_{2}$ will be 0.60 cubic feet per hour (CFH) and at moderate activity it will be $4.2 \mathrm{CFH}$. Taking these respective oxygen consumptions and using the weighted averages activity levels yields an assumed $\mathrm{O}_{2}$ breathing rate of $1.32 \mathrm{CFH}$ as shown below in the following calculations (MSHA, 2007).

For activity level of $4 / 5$ of the time at rest

$$
\begin{aligned}
& \frac{4}{5} \cdot\left(\frac{\text { Breathing rate of } \mathrm{O}_{2} \text { per miner }}{\text { per hour }}\right) \\
= & \frac{4}{5} \cdot\left(\frac{0.60 \mathrm{CFH} \text { of } \mathrm{O}_{2} \text { per miner }}{\text { per hour }}\right)=0.48 \mathrm{CFH} \text { per person }
\end{aligned}
$$

For activity level of $1 / 5$ of the time at moderate activity

$$
\begin{aligned}
& \frac{1}{5} \cdot\left(\frac{\text { Breathing rate of } \mathrm{O}_{2} \text { per miner }}{\text { per hour }}\right) \\
& \quad=\frac{1}{5} \cdot\left(\frac{4.2 \mathrm{CFH} \text { of } \mathrm{O}_{2} \text { per miner }}{\text { per hour }}\right)=0.84 \mathrm{CFH} \text { of } \mathrm{O}_{2} \text { per miner }
\end{aligned}
$$

This gives the amount of $\mathrm{O}_{2}$ that MSHA assumes each miner will consume each hour.

$$
0.48 \mathrm{CFH} \text { per miner }+0.84 \mathrm{CFH} \text { per miner }=1.32 \mathrm{CFH} \text { per miner }
$$


Using the results of Eq. (4-2) the amount of oxygen that will be consumed per miner in any amount of time can be calculated. The following is the calculation of the amount of oxygen needed per miner for a 96-hour time period, since this is the time period MSHA regulations require for life support in the design of a refuge shelter.

\section{$1.32 \mathrm{ft}^{3}$ per miner $\cdot 96$ hours $=126.72 \mathrm{CF}$ per miner}

For a 10 miner refuge shelter the amount of $\mathrm{O}_{2}$ needed for a 96-hour period is calculated as:

$$
126.72 \mathrm{ft}^{3} \text { of } \mathrm{O}_{2} \text { used per miner } \cdot 10 \text { miners }=1267.2 \frac{\mathrm{ft}^{3}}{\text { Shelter }}
$$

To supply $\mathrm{O}_{2}$ in the underground refuge shelters, the manufacturer will use compressed air cylinders. MSHA recommends the use of K-sized grade D compressed oxygen cylinders. The air quality of grade D compressed oxygen cylinders is shown in Table 4.3.

Table 4.3 Air Quality of Grade D Compressed Oxygen Cylinders (MSHA, 2007).

\begin{tabular}{|c|l|}
\hline Component & Quality \\
\hline $\mathrm{O}_{2}$ & $19.5 \%$ to $23.5 \%$ \\
\hline $\mathrm{CO}$ & $10 \mathrm{PPM} \max$ \\
\hline $\mathrm{CO}_{2}$ & $1000 \mathrm{PPM} \max$ \\
\hline Oil & $5 \mathrm{mg} / \mathrm{m}^{3} \max$ \\
\hline Odor & lack of noticeable odor \\
\hline
\end{tabular}


The K-sized grade D air cylinders come in different volumes, dependent on the pressure inside the cylinder. If the fill pressure inside each cylinder is equal to 2,400 psi, then the volume of $\mathrm{O}_{2}$ in each cylinder is equal to $310 \mathrm{ft}^{3}$ (MSHA, 2007).

Knowing the cylinder volume allows for calculating the number of $\mathrm{O}_{2}$ cylinders required for a shelter with 10 miners using Eq. (4-4). For a 10 person shelter:

$$
\begin{gathered}
\frac{\text { Number of } \mathrm{O}_{2} \text { cylinders needed }}{10 \text { miners shelter / chamber }}=\frac{\text { Amount of } \mathrm{O}_{2} \text { needed for } 10 \text { miners }}{\text { Amount of } \mathrm{O}_{2} \text { per cylinder }} \\
=\frac{1267.2 \mathrm{ft}^{3}}{310 \mathrm{ft}^{3}}=\frac{5 \mathrm{O}_{2} \text { cylinders needed }}{\text { per } 10 \text { person shelter } / \text { chamber }}
\end{gathered}
$$

The result suggests that at least five oxygen cylinders will be needed to sustain the life of 10 miners for a duration of 96-hours in an underground refuge shelter.

To keep toxic gases and other contaminants produced from an explosion inside a mine, the metal refuge shelters will also contain an airlock section for entering. This section will be able to hold all of the miners, so that the air in the airlock section can be purged with compressed air. This is done so the contaminants from outside the shelter are diluted and won't get into the main compartment of the shelter once the miners enter. The purge air oxygen cylinders will be used in conjunction with a one way pressure valve that will let air escape the airlock as it is being purged to let the contaminants out and avoid creating high pressure inside the chamber.

The air lock section will be equipped with a multi-gas detector capable of monitoring $\mathrm{CO}, \mathrm{CO}_{2}, \mathrm{O}_{2}$, and $\mathrm{CH}_{4}$. This will allow the miners to determine when the atmosphere inside the airlock is breathable and it is safe to enter the shelter. 


\subsubsection{Carbon Monoxide Parameters}

The Carbon Monoxide (CO) in the atmosphere is often referred to as the silent killer because it is colorless, odorless, and tasteless gas that can be lethal if a human is exposed to it in high enough concentrations for a long period of time. When carbon monoxide is present, it is usually a result of incomplete combustion. Some of the symptoms that may occur during prolonged exposure to carbon monoxide include dizziness, disorientation, nausea, and fatigue at concentrations less than $100 \mathrm{ppm}$ (Hartman et. al., 1997). Concentrations as low as 667 ppm can cause up to nearly $50 \%$ of the body's hemoglobin to be converted to carboxy hemoglobin $(\mathrm{COHb})$, which inhibits oxygen intake into the body. Exposures to this level can be life threatening. Many people that die from carbon monoxide poisoning do not even realize what is taking place and silently slip into unconsciousness. Table 4-4 describes the various effects that take place when exposed to carbon monoxide for a prolonged period of time (EPA, 2007). 
Table 4.4 Effects of Carbon Monoxide (CO) Poisoning (Hartman et. al, 1997).

\begin{tabular}{|c|c|}
\hline $\begin{array}{c}\text { Blood Saturation \% of COHb } \\
\text { (Carboxy hemoglobin) }\end{array}$ & Symptoms \\
\hline $5-10$ & First noticeable effect, loss of some cognitive function \\
\hline $10-20$ & Tightness across forehead, possible headache \\
\hline $20-30$ & $\begin{array}{r}\text { Severe headache, weakness, dizziness, dimness of } \\
\text { vision, nausea and vomiting, and collapse }\end{array}$ \\
\hline $30-40$ & $\begin{array}{r}\text { Increased likelihood of collapse and unconsciousness, } \\
\text { coma with intermittent convulsions }\end{array}$ \\
\hline $40-60$ & Coma, possible death \\
\hline $60-70$ & Respiratory failure, death \\
\hline $70-80$ &
\end{tabular}

In the design of underground coal mine refuge shelters, it is very important to consider the possibility of carbon monoxide poisoning and what could occur in the event of a fire or an explosion. It is very important to remember that if there was severe damage to the shelter itself that allowed outside gases to leak inside then the air quality control would not work anyway.

\subsubsection{Carbon Dioxide Parameters}

In a closed space carbon dioxide $\left(\mathrm{CO}_{2}\right)$ can be just as fatal as the well known killer, carbon monoxide and is a naturally occurring part of the earth's atmosphere at a concentration of about 0.03 percent. This small percentage is produced from naturally occurring human and animal metabolisms. In a confined atmosphere with no ventilation coming in from the outside, the human breathing cycle will cause the concentration of 
carbon dioxide to buildup. With this buildup the vital processes of the human body can be significantly influenced including effecting vascular constriction or dilation, body fluid $\mathrm{pH}$, and their ability to control their own breathing (EPA, 2007).

Carbon dioxide inhalation can have various effects including dizziness, headaches, tremors, convulsions, unconsciousness, and breathing higher concentrations can lead to death. If someone is exposed to concentration levels of $1-1.5 \%$ percent carbon dioxide they can tolerate it with little noticeable respiratory stimulation. Once the carbon dioxide levels reach 3\%, noticeable effects such as headaches, diffuse sweating, and dyspnea can occur if someone is exposed to it for a prolonged period of time. When concentrations go even higher up to $10 \%$, the effects become more severe as exposure to this level can lead to unconsciousness and tremors in only a short period of time. Any exposure to carbon dioxide at concentrations of 10 percent or above can quickly lead to unconsciousness, convulsions, coma, and even death within only a few minutes (EPA, 2007). Table 4.5 presents the possible physiological effects various concentrations of carbon dioxide can have on humans. 
Table 4.5 The Physiological Effects of High Concentrations of Carbon Dioxide (EPA, 2007).

\begin{tabular}{|c|c|c|}
\hline $\begin{array}{c}\text { Carbon Dioxide } \\
\text { Concentration }(\%)\end{array}$ & Time & Effects \\
\hline $17-30$ & Within 1 minute & $\begin{array}{l}\text { Loss of controlled and } \\
\text { purposeful activity, } \\
\text { unconsciousness, } \\
\text { convulsions, coma, death }\end{array}$ \\
\hline $10-15$ & $\begin{array}{l}1 \text { minute to several } \\
\text { minutes }\end{array}$ & $\begin{array}{l}\text { Dizziness, drowsiness, } \\
\text { severe mu scle twitching, } \\
\text { unconsciousness }\end{array}$ \\
\hline $7-10$ & $\begin{array}{l}\text { Few minutes } \\
1.5 \text { minutes to } 1 \text { hour }\end{array}$ & $\begin{array}{l}\text { Unconsciousness, near } \\
\text { unconsciousness } \\
\text { Headache, increases heart } \\
\text { rate, shortness of breath, } \\
\text { dizziness, sweating, rapid } \\
\text { breathing }\end{array}$ \\
\hline 6 & $\begin{array}{l}1 \text { - } 2 \text { minutes } \\
\text { Less than } 16 \text { minutes } \\
\text { Several hours }\end{array}$ & $\begin{array}{l}\text { Hearing and visual } \\
\text { disturbances } \\
\text { Headache, dyspnea } \\
\text { Tremors }\end{array}$ \\
\hline $4-5$ & Within a few minutes & $\begin{array}{l}\text { Headache, dizziness, } \\
\text { increased blood pressure, } \\
\text { uncomfortable dyspnea }\end{array}$ \\
\hline 3 & 1 hour & $\begin{array}{l}\text { Mild headache, sweating, } \\
\text { and dyspnea at rest }\end{array}$ \\
\hline 2 & Several hours & $\begin{array}{l}\text { Headache, dyspnea upon } \\
\text { mild exertion }\end{array}$ \\
\hline
\end{tabular}

As shown in Table 4.5 it is vitally important to consider carbon dioxide concentrations in the design of an underground coal refuge shelter. The only current technologies available to keep $\mathrm{CO}_{2}$ levels below the $3 \%$ level (besides increasing the volume of the shelter) is called carbon dioxide scrubbing. All of the shelter manufacturers use carbon dioxide scrubbing whereby chemicals such as lithium hydroxide (LiOh) or 
soda lime $\left(\mathrm{NaHCO}_{3}\right)$, remove the $\mathrm{CO}_{2}$ from the atmosphere. This technique is commonly used aboard submarines and spacecraft.

The lithium hydroxide scrubbing system utilizes a chemical curtain to filter out the carbon dioxide. This is a passive system, so it does not require energy to be effective. The chemical reaction is shown below.

$$
2 \mathrm{LiOH}+\mathrm{CO}_{2} \rightarrow \mathrm{Li}_{2} \mathrm{CO}_{3}+\mathrm{H}_{2} \mathrm{O}
$$

This is an anhydrous hydroxide reaction and is preferred for its lower mass and little water production in respiratory systems such as submarines (EAC, 2007).

The amount of lithium hydroxide needed to sustain 10 miners for four days can now be calculated as shown below.

$$
\mathrm{CO}_{2} \text { Generation }=1.08 \mathrm{CFH} \text { per miner } \cdot 10 \text { miners } \cdot 96 \text { hours }=1037 \mathrm{ft}^{3} \text { of } \mathrm{CO}_{2}
$$

Take the volume of carbon dioxide generated and convert it to pounds. Then calculate the amount of lithium hydroxide needed as 1 pound of lithium hydroxide absorbs 0.794 pounds of carbon dioxide (EAC, 2007).

lbs of $\mathrm{LiOH}$ needed $=1037 \mathrm{ft}^{3}$ of $\mathrm{CO}_{2} \cdot \frac{0.1144 \mathrm{lbs} \text { of } \mathrm{CO}_{2}}{\mathrm{ft}^{3}} \cdot \frac{1 \mathrm{lb} \mathrm{LiOH}}{0.794 \mathrm{lbs} \mathrm{CO}_{2}} \cong 150 \mathrm{lbs} \mathrm{LiOH}$

The amount of lithium hydroxide needed to sustain the life of 10 miners for four days is $150 \mathrm{lbs}$. The curtains come packaged in boxes that contain 5.7 pounds of lithium hydroxide per box from the ExtendAir Company. Therefore for a 10 miner shelter there would have to be 27 boxes of lithium hydroxide stored in it to support the miners lives. The curtains need to simply be hung up and they will filter the $\mathrm{CO}_{2}$ as the air circulates in 
the shelter. The curtains just need to be replaced every 12 hours as illustrated in Figure 4.1 (EAC, 2007).



Figure 4.1 Lithium Hydroxide (LiOH) Absorption Curves, (EAC, 2007).

The other chemical technique used for the removal of carbon dioxide from the atmosphere is done utilizing a product called soda lime. This is achieved by the use of canisters filled with soda lime and fitted to an absorption unit where air is drawn through the canisters with compressed air requiring no power. Soda lime removes carbon dioxide in a series of three reactions. The first reaction combines the carbon dioxide with water to get carbon dioxide in solution. The second reaction combines the carbon dioxide solution with sodium hydroxide $(\mathrm{NaOH})$ to form sodium bicarbonate $\left(\mathrm{NaHCO}_{3}\right)$. The sodium bicarbonate is then reacted with calcium hydroxide $(\mathrm{CaOH})$ to form calcium carbonate $\left(\mathrm{CaCO}_{3}\right)$, sodium hydroxide, and water. The series of reactions are shown om the next page (Rendell, 2007). 

1) Hydration Reaction
$\mathrm{CO}_{2}+\mathrm{H}_{2} \mathrm{O} \rightarrow \mathrm{CO}_{2}$
2) $\mathrm{CO}_{2}$ Reaction
$\mathrm{CO}_{2}+\mathrm{NaOH} \rightarrow \mathrm{NaHCO}_{3}$
3) Intermediate Reaction
$\mathrm{NaHCO}_{3}+\mathrm{Ca}(\mathrm{OH})_{2} \rightarrow \mathrm{CaCO}_{3}+\mathrm{NaOH}+\mathrm{H}_{2} \mathrm{O}$
4) Overall Reaction
$\mathrm{CO}_{2}+\mathrm{Ca}(\mathrm{OH})_{2} \rightarrow \mathrm{CaCO}_{3}+\mathrm{H}_{2} \mathrm{O}$ 


\section{Chapter 5}

\section{Temperature Requirements Inside Shelters}

The state of WVOMHST and MSHA require that an apparent temperature of no higher than 95 degrees Fahrenheit be maintained inside the coal mine refuge shelters. This chapter will discuss the shelters abilities to maintain the required apparent temperature.

\subsection{Procedure for Determining the Apparent Temperature}

The approach to calculate the apparent temperature, often referred to as the heat index, will be performed using a Heating, Ventilation, and Air Conditioning (HVAC) approach. This method will require the calculation of the steady state air temperature (dry bulb temperature) and the steady state specific humidity. The apparent temperature is a measurement of the air temperature in relation to specific humidity. As a result the calculation of the apparent temperature can be determined based on their two values.

The information for procedures used in this approach were obtained from the American Society of Heating, Refrigerating, and Air Conditioning Engineers (ASHRAE). In order to properly solve the apparent temperature calculations all the heat inputs of each person/miner are broken down by ASHRAE into latent heat (heat absorbed) and sensible heat (heat related to a temperature change). For the lowest level of human activity, ASHRAE gives the value of the latent and sensible heat generated by one person/miner as: 


$$
\begin{aligned}
& \mathrm{q}_{\text {sensible }}=70\left(\frac{\mathrm{W}}{\text { person }}\right) \\
& \mathrm{q}_{\text {latent }}=45\left(\frac{\mathrm{W}}{\text { person }}\right) \\
& \mathrm{q}_{\text {total }}=115\left(\frac{\mathrm{W}}{\text { person }}\right)
\end{aligned}
$$

Where:

$\mathrm{q}$ is equal to heat, Watts $(\mathrm{W})$.

There is another addition to the sensible heat in the shelters due to the sensible heat added to the system from the $\mathrm{CO}_{2}$ scrubber. The additional sensible heat is determined by multiplying the total heat by an 8 percent factor (ASHRAE, 1993).

$$
117.24 \mathrm{~W} \cdot 0.08=9.38 \mathrm{~W}
$$

The additional value must be added to $\mathrm{q}_{\text {total }}$ and $\mathrm{q}_{\text {sensible, }}$ therefore the new values are

$$
\begin{gathered}
\mathrm{q}_{\text {sensible }}=80.74 \mathrm{~W} \\
\mathrm{q}_{\text {latent }}=45.88 \mathrm{~W} \\
\mathrm{q}_{\text {total }}=126.62 \mathrm{~W}
\end{gathered}
$$

Using the new total heat results, the apparent temperature can be determined. First, the calculation of the temperature of the wall $\left(\mathrm{T}_{\text {wall }}\right)$ is carried out beginning with Eq. (5-1) as shown below.

$$
\mathrm{q}_{\text {total }}=\mathrm{h}_{0} \cdot \mathrm{A}\left(\mathrm{T}_{\text {wall }}-\mathrm{T}_{\text {outside }}\right)
$$

rearranging the terms and plugging Eq. (5-3) in for either $h_{0}$ or $h_{i}$, the temperature of the 
wall can be determined as shown in Eq. (5-2).

$$
\mathrm{T}_{\text {wall }}=\mathrm{T}_{\text {outside }}+\left(\frac{\mathrm{q}_{\text {total }}}{\mathrm{h}_{0} \cdot \mathrm{A}}\right)^{\left(\frac{1}{1.33}\right)}
$$

Where:

$\mathrm{A}=$ total area of the inside of the shelter, $\mathrm{m}^{2}$

$\mathrm{T}_{\text {wall }}=$ temperature of the wall inside the shelter, $\mathrm{C}$

$\mathrm{q}_{\mathrm{total}}=$ total heat generated in the shelter per miner, $\mathrm{W}$

$\mathrm{h}_{0}=$ the outside heat transfer coefficient, $\frac{\mathrm{btu}}{\mathrm{hr} \cdot \mathrm{ft}^{2} \cdot \mathrm{F}}$

$\mathrm{T}_{\text {outside }}=$ the temperature of the atmosphere outside of the shelter, $\mathrm{C}$

The area, A, can be calculated for any size of shelter and the shelters have a thermometer to show the outside temperature at all times. Using the outside temperature, the value of the outside, $\mathrm{h}_{\mathrm{o}}$, heat transfer coefficient can be determined using Eq. (5-3). This equation can also be used to calculate the inside heat transfer coefficient once the temperature inside the shelter is known. These coefficients are often used when calculating heat transfer by convection, which is simply the movement of heat from one place to another, in this case through the walls of the shelters (ASHRAE, 1993).

$$
\mathrm{h}_{\mathrm{o}, \mathrm{i}}=1.31 \cdot(\operatorname{del~T})^{0.33}\left(\frac{\mathrm{w}}{\mathrm{m}^{2} \cdot \mathrm{K}}\right)
$$


Where:

$\mathrm{h}_{\mathrm{o}} \mathrm{i}=$ the outside or inside transfer coefficient, $\left(\frac{\mathrm{btu}}{\mathrm{hr} \cdot \mathrm{ft}^{2} \cdot \mathrm{F}}\right)$

del $\mathrm{T}=\mathrm{T}_{\text {wall }}-\mathrm{T}_{\text {outside }}$ when calculating $\mathrm{h}_{0}$ or $\mathrm{T}_{\text {room }}-\mathrm{T}_{\text {wall }}$ when calculating $\mathrm{h}_{\mathrm{i}}$ (ASHRAE, 1993).

After obtaining the final results for the temperature of the wall $\left(T_{\text {wall }}\right)$ the next step can be taken to calculate what the temperature inside the shelter $\left(\mathrm{T}_{\text {room }}\right)$ will be. This temperature is simply the air temperature inside the shelters and will be one of the main terms needed in the calculation of the apparent temperature. The process to calculate the air temperature inside the shelter begins with Eq. (5-4).

$$
\mathrm{q}_{\text {sensible }}=\mathrm{h}_{\mathrm{i}} \cdot \mathrm{A}\left(\mathrm{T}_{\text {room }}-\mathrm{T}_{\text {wall }}\right)
$$

Rearranging the terms gives the equation to determine the temperature inside the shelter as shown in Eq. (5-5).

$$
\mathrm{T}_{\text {room }}=\mathrm{T}_{\text {wall }}+\left(\frac{\mathrm{q}_{\text {sensible }}}{\mathrm{h}_{\mathrm{i}} \cdot \mathrm{A}}\right)
$$

Where:

$\mathrm{T}_{\mathrm{room}}=$ air temperature in the room, $\mathrm{C}$

$\mathrm{q}_{\text {sensible }}=$ total sensible heat generated in the shelter per person/miner, $\mathrm{W}$

$\mathrm{h}_{\mathrm{i}}=$ inside heat transfer coefficient, $\left(\frac{\mathrm{btu}}{\mathrm{hr} \cdot \mathrm{ft}^{2} \cdot \mathrm{F}}\right)$ 
The inside heat transfer coefficient can be determined using Eq. (5-3). This is the same equation used to calculate the outside heat transfer coefficient, the only difference is the del T which is simply the change in temperature (ASHRAE, 1993).

After obtaining the values for $\mathrm{T}_{\text {wall }}$ and $\mathrm{T}_{\text {room }}$ Eq. (5-6) can be used to determine the specific humidity inside the shelter $\left(\mathrm{W}_{\text {room }}\right)$.

$$
\mathrm{q}_{\text {latent }}=\mathrm{K}_{\mathrm{m}} \cdot \mathrm{A}\left(\mathrm{W}_{\text {room }}-\mathrm{W}_{\text {wall }}\right) \cdot \mathrm{h}_{\mathrm{fg}}
$$

and

$$
\mathrm{K}_{\mathrm{m}}=\left(\frac{\mathrm{h}_{\text {inside }}}{\mathrm{C}_{\mathrm{pm}}}\right)
$$

Where:

$\mathrm{K}_{\mathrm{m}}=$ mass transfer coefficient, $\left(\frac{\mathrm{g}}{\mathrm{m}^{2} \cdot \mathrm{s}}\right)$

$\mathrm{W}_{\text {room }}=$ specific humidity in the shelter, $\left(\frac{\mathrm{g}_{\text {water vapa }}}{\mathrm{g}_{\text {dry air }}}\right)$

$\mathrm{W}_{\text {wall }}=$ specific humidity of the wall in the shelter, $\left(\frac{\mathrm{g}_{\text {water vapo }}}{\mathrm{g}_{\text {dryair }}}\right)$, this number can be read from a psychometric chart by simply reading the specific humidity at the point where the temperature of the wall $\left(\mathrm{T}_{\text {wall }}\right)$ found in Eq. (5-3) meets the saturation temperature curve.

$\mathrm{h}_{\mathrm{fg}}=$ the heat condensation constant of steam into water, $2257\left(\frac{\mathrm{J}}{\mathrm{g}}\right)$

$\mathrm{h}_{\text {inside }}=$ result obtained from Eq. $(5-4), \frac{\mathrm{btu}}{\mathrm{hr} \cdot \mathrm{ft}^{2} \cdot \mathrm{F}}$ 
$\mathrm{C}_{\mathrm{pm}}=$ specific heat of humid air constant, $1.005\left(\frac{\mathrm{J}}{\mathrm{g} \cdot \mathrm{K}}\right)$,

Therefore the specific humidity of the atmosphere inside the shelter $\left(\mathrm{W}_{\text {room }}\right)$ is determined as:

$$
\mathrm{W}_{\text {room }}=\mathrm{W}_{\text {wall }}+\left(\frac{\mathrm{q}_{\text {latent }} \cdot \mathrm{C}_{\mathrm{pm}}}{\mathrm{A} \cdot \mathrm{h}_{\mathrm{fg}} \cdot 1.31\left(\mathrm{~T}_{\mathrm{room}}-\mathrm{T}_{\text {wall }}\right)^{0.33}}\right)
$$

Using the results obtained from Eq. (5-8) the relative humidity in the room can be determined on a psychometric chart. This is done by finding the point on the psychometric chart where the specific humidity of the room $\left(\mathrm{W}_{\text {room }}\right)$ connects to the air temperature in the room $\left(\mathrm{T}_{\text {room }}\right)$. Once the relative humidity is determined, the apparent temperature can be calculated using Eq. (5-9).

Apparent Temperature $=-42.379+\left(2.04901523\left(\mathrm{~T}_{\text {room }}\right)\right)+(10.14333127(\mathrm{RH}))-$ $\left(0.22475541\left(\mathrm{~T}_{\text {room }}\right)(\mathrm{RH})\right)-\left(\left(6.83783 \times 10^{-3}\right)\left(\mathrm{T}_{\text {room }}{ }^{2}\right)\right)-\left(\left(5.481717 \times 10^{-2}\right)\left(\mathrm{RH}^{2}\right)\right)+$ $\left(\left(1.22874 \times 10^{-3}\right)\left(\mathrm{T}_{\text {room }}^{2}\right)(\mathrm{RH})\right)+\left(\left(8.5282 \times 10^{-4}\right)\left(\mathrm{T}_{\text {room }}\right)\left(\mathrm{RH}^{2}\right)\right)-$ $\left(\left(1.99 \times 10^{6}\right)\left(\mathrm{T}_{\text {room }}^{2}\right)\left(\mathrm{RH}^{2}\right)\right)$

Where:

$\mathrm{T}_{\text {room }}=$ air temperature (dry bulb temperature) inside the shelter, $\mathrm{F}$

$\mathrm{RH}=$ relative humidity as read from the psychrometric chart, \% (Steadman, 1979)

All the equations required to determine the apparent temperature inside of the underground coal refuge shelters have now been determined. Now an example will be carried out using Eqs. (5-1) through (5-9). This example will be for a shelter with an occupancy limit of 10 miners and the room size will be $7 \mathrm{ft}$ high $\mathrm{x} 7 \mathrm{ft}$ wide $\mathrm{x} 13 \mathrm{ft}$ long. 
The temperature outside of the shelter must also be known and in this example 12.78 degree celsius ( 55 degrees F) will be used. The total area of the chamber can be determined first using Eq. (5-11).

$$
\mathrm{A}_{\text {total }}=7 \cdot(13+13+13+13+7+7)=462 \mathrm{ft}^{2}
$$

Converting to $\mathrm{m}^{2}$ gives the following:

$$
462 \mathrm{ft}^{2} \cdot 0.09290 \frac{\mathrm{m}^{2}}{\mathrm{ft}^{2}}=42.92 \mathrm{~m}^{2}
$$

Where:

$0.09290\left(\frac{\mathrm{m}^{2}}{\mathrm{ft}^{2}}\right)$ is the conversion factor needed to convert $\mathrm{ft}^{2}$ to $\mathrm{m}^{2}$.

These calculations are for a 10-person shelter, so the total heat, total sensible heat, and total latent heat must be determined using the previous values given for these terms per person.

$$
\begin{gathered}
\mathrm{q}_{\text {sensible }}=80.74 \mathrm{~W} \text { per miner } \cdot 10 \text { miners }=807.4 \mathrm{~W} \\
\mathrm{q}_{\text {latent }}=45.88 \mathrm{~W} \text { per miner } \cdot 10 \text { miners }=458.8 \mathrm{~W} \\
\mathrm{q}_{\text {total }}=807.4 \mathrm{~W}+458.8 \mathrm{~W}=1266.2 \mathrm{~W}
\end{gathered}
$$

The calculation of $\mathrm{T}_{\text {wall }}$ can be determined beginning with Eq. (5-2)

$$
\mathrm{T}_{\text {wall }}=\mathrm{T}_{\text {outside }}+\left(\frac{\mathrm{q}_{\text {total }}}{\mathrm{h}_{0} \cdot \mathrm{A}}\right)
$$


The terms are rearranged and Eq. (5-3) is substituted for the outside heat transfer coefficient, $\mathrm{h}_{0}$. This will allow $\mathrm{T}_{\text {wall }}$ to be calculated as shown below with $\mathrm{q}_{\text {total }}=1266.2$ $\mathrm{W}, \mathrm{A}=42.92 \mathrm{~m}^{2}$, and $\mathrm{T}_{\text {outside }}=12.78 \mathrm{C}$.

$$
\mathrm{T}_{\text {wall }}=12.78 \mathrm{C}+\left(\frac{1266.2 \mathrm{~W}}{1.31 \cdot 42.92 \mathrm{~m}^{2}}\right)^{\left(\frac{1}{1.33}\right)}=23.18 \text { degrees } \mathrm{C} \text { or } 73.7 \text { degrees } \mathrm{F}
$$

Now by using Eq. (5-3) again the outside heat transfer coefficient $\left(\mathrm{h}_{0}\right)$ can be calculated as shown here where $\mathrm{T}_{\text {wall }}=23.18 \mathrm{C}(73.7 \mathrm{~F})$ and $\mathrm{T}_{\text {outside }}=12.78 \mathrm{C}(55 \mathrm{~F})$.

$$
\mathrm{h}_{\text {outside }}=\left(\mathrm{T}_{\text {wall }}-\mathrm{T}_{\text {outside }}\right)^{0.33}=1.31(23.18 \mathrm{C}-12.78 \mathrm{C})^{0.33}=0.500\left(\frac{\mathrm{btu}}{\mathrm{hr} \cdot \mathrm{ft}^{2} \cdot \mathrm{F}}\right)
$$

Using these results the calculation of the temperature in the room $\left(\mathrm{T}_{\text {rrom }}\right)$ can be performed using Eq. (5-5) and Eq. (5-3) is substituted for $\mathrm{h}_{\mathrm{i}}$ as shown below where

$$
\begin{aligned}
& \mathrm{q}_{\text {sensible }}=807.4 \mathrm{~W}, \mathrm{~A}=42.92 \mathrm{~m}^{2}, \text { and } \mathrm{T}_{\text {wall }}=23.18 \mathrm{C}(73.7 \mathrm{~F}) \\
& \mathrm{T}_{\text {room }}=23.18 \mathrm{C}+\left(\frac{807.4 \mathrm{~W}}{1.31 \cdot 42.92 \mathrm{~m}^{2}}\right)=30.59 \mathrm{C} \text { or } 87.06 \mathrm{~F}
\end{aligned}
$$

Next, by using Eq. (5-3) the inside heat transfer coefficient, $\mathrm{h}_{\mathrm{i}}$, can be calculated as shown where $\mathrm{T}_{\text {room }}=30.59 \mathrm{C}(87.06 \mathrm{~F})$ and $\mathrm{T}_{\text {wall }}=23.18 \mathrm{C}(73.7 \mathrm{~F})$.

$$
\mathrm{h}_{\mathrm{i}}=1.31(30.59-23.18)^{0.33}=0.447\left(\frac{\mathrm{btu}}{\mathrm{hr} \cdot \mathrm{ft}^{2} \cdot \mathrm{F}}\right)
$$


Next, in the final step of calculations the specific humidity of the room inside the shelter must be determined. This is done by using Eqs. (5-6), (5-7) and (5-8) as shown below with $\mathrm{T}_{\text {room }}=30.59 \mathrm{C}, \mathrm{T}_{\text {wall }}=23.18 \mathrm{C}, \mathrm{q}_{\text {latent }}=458.8 \mathrm{~W}, \mathrm{c}_{\mathrm{pm}}=1.005\left(\frac{\mathrm{J}}{\mathrm{g} \cdot \mathrm{K}}\right)$, $\mathrm{h}_{\mathrm{fg}}=2257\left(\frac{\mathrm{J}}{\mathrm{g}}\right), \mathrm{A}=42.92 \mathrm{~m}^{2}$ and $\mathrm{W}_{\text {wall }}=0.0180\left(\frac{\mathrm{g}_{\text {moisture }}}{\mathrm{g}_{\text {dry air }}}\right)$. The value for $\mathrm{c}_{\mathrm{pm}}$ and $\mathrm{h}_{\mathrm{fg}}$ are constants and were obtained from ASHRAE (ASHRAE, 1993). The value for the specific humidity of the wall $\left(\mathrm{W}_{\text {wall }}\right)$ is obtained from a psychrometric chart by matching the temperature of the wall $\left(\mathrm{T}_{\text {wall }}\right)$ with the saturation curve and then reading the specific humidity at this point. The calculation of the specific humidity of the room can now be carried out using Eq. (5-8) as shown below.

$\left.\mathrm{W}_{\text {room }}=0.0180\left(\frac{\mathrm{g}_{\text {moisture }}}{\mathrm{g}_{\text {dry air }}}\right)+\left(\frac{458.8 \mathrm{~W} \cdot 1.005\left(\frac{\mathrm{J}}{\mathrm{g} \cdot \mathrm{K}}\right)}{42.94 \mathrm{~m}^{2} \cdot 2257\left(\frac{\mathrm{J}}{\mathrm{g}}\right) \cdot 1.31(30.59-23.18)^{0.33}}\right)=0.0198 \S \frac{\mathrm{g}_{\text {moisture }}}{\mathrm{g}_{\text {dry air }}}\right)$

After obtaining the specific humidity of the shelter room it can be used to determine the relative humidity $(\mathrm{RH})$ inside the shelter. This is done by finding the relative humidity $(\%)$ at the point on a psychrometric chart where the temperature of the room $\left(\mathrm{T}_{\text {room }}\right)$ meet the specific humidity of the room $\left(\mathrm{W}_{\text {room }}\right)$ and in this case the relative humidity is equal to 72 percent. To determine the apparent temperature $\left(\mathrm{T}_{\text {apparent }}\right)$, Eq. (59) can be used with $\mathrm{T}_{\text {room }}=30.59 \mathrm{C}$ and $\mathrm{RH}=72 \%$ as shown below.$$
\mathrm{T}_{\text {apparent }}(\text { heat index })=-42.379+(2.04901523(30.59 \mathrm{C}))+(10.14333127(72 \%))-
$$$$
(0.22475541(30.59 \mathrm{C})(72 \%))-\left(\left(6.83783 \times 10^{-3}\right)\left(30.59 \mathrm{C}^{2}\right)\right)-
$$ 
$\left(\left(5.481717 \times 10^{-2}\right)\left(72 \%^{2}\right)\right)+\left(\left(1.22874 \times 10^{-3}\right)\left(30.59 \mathrm{C}^{2}\right)(72 \%)\right)+$

$\left(\left(8.5282 \times 10^{-4}\right)(30.59 \mathrm{C})\left(72 \%^{2}\right)\right)-\left(\left(1.99 \times 10^{6}\right)\left(30.59 \mathrm{C}^{2}\right)\left(72 \%^{2}\right)\right)=$

34.5 C or $94.1 \mathrm{~F}$

The results from Eq. (5-9) show that the regulation in the state of WV that a shelter maintain an apparent temperature of 95 degrees Fahrenheit is being met in the design of the underground refuge shelters.

\section{Summary}

The West Virginia regulations require an apparent temperature of no more than 95 degrees Fahrenheit. This chapter uses an HVAC method commonly used by American Society of Heating, Refrigerating, and Air Conditioning Engineers (ASHRAE) to determine the apparent temperature in applications such as the underground coal refuge shelters. The method requires the use of heat transfer equations, constants, and a psychrometric chart to determine the apparent temperature inside a closed area, such as underground coal refuge shelters. 


\section{Appendices A}

\section{Appendix A-1 Some Quality Properties of Available Underground Coal Refuge Shelter (MSHA, 2007).}

\begin{tabular}{|c|c|c|c|c|c|c|}
\hline & $\begin{array}{l}\text { ChemBio } \\
\text { Shelters }\end{array}$ & $\begin{array}{l}\text { Strata } \\
\text { Shelters }\end{array}$ & $\begin{array}{l}\text { Kennedy } \\
\text { Shelters }\end{array}$ & $\begin{array}{l}\text { MineArc } \\
\text { Shelters }\end{array}$ & $\begin{array}{l}\text { Modern } \\
\text { Mine } \\
\text { Supply } \\
\text { Shelters } \\
\end{array}$ & $\begin{array}{l}\text { Draeger } \\
\text { Shelters }\end{array}$ \\
\hline Life Support & 96 hours & 96 hours & 96 hours & 96 hours & 96 hours & 96 hours \\
\hline $\begin{array}{c}\text { CO2 and CO } \\
\text { Scrubbing }\end{array}$ & Both & Yes & Yes & Yes & Yes & Yes \\
\hline $\begin{array}{c}\text { CO2 } \\
\text { Scrubbing } \\
\text { Type }\end{array}$ & $\begin{array}{l}\text { Soda-Lime or } \\
\text { (LiOH) }\end{array}$ & $\begin{array}{l}\text { Soda-Lime or } \\
\text { (LiOH) }\end{array}$ & (LiOH) & & Soda Lime & Soda-Lime \\
\hline $\begin{array}{c}\text { Softwalled or } \\
\text { Hardwalled }\end{array}$ & Soft-Walled & $\begin{array}{c}\text { Hard-Walled } \\
\text { and Soft- } \\
\text { Walled }\end{array}$ & Soft-Walled & Hard-Walled & Hard-Walled & Hard-Walled \\
\hline Fire Retardant & Yes & Yes & Yes & Yes & Yes & Yes \\
\hline Movable & Yes & Yes & Yes & Yes & Yes & Yes \\
\hline $\begin{array}{l}\text { High Seam or } \\
\text { Low Seam }\end{array}$ & Both & Both & High Seam & Both & High Seam & Both \\
\hline $\begin{array}{l}\text { Maximum } \\
\text { Capacity }\end{array}$ & 18 - persons & 24 persons & 10 -persons & 20 - persons & 16 - persons & 16 \\
\hline $\begin{array}{l}\mathrm{CO}, \mathrm{CO} 2 \text {, and } \\
\text { Oxygen } \\
\text { Monitors }\end{array}$ & Yes & Yes & Yes & Yes & Yes & Yes \\
\hline $\begin{array}{c}\text { Emergency } \\
\text { Medical } \\
\text { Supplies }\end{array}$ & Yes & Yes & Yes & Yes & Yes & Yes \\
\hline $\begin{array}{l}\text { Waste } \\
\text { Disposal }\end{array}$ & Yes & Yes & Yes & Yes & Yes & Yes \\
\hline Customizeable & Yes & Yes & Yes & Yes & Yes & Yes \\
\hline $\begin{array}{c}\text { Require Power } \\
\text { or Batteries }\end{array}$ & Batteries & Batteries & Batteries & Batteries & Batteries & Batteries \\
\hline
\end{tabular}




\title{
Appendix A-2 A list of Underground Refuge Shelter Requirements in the state of WV (WVOMHST, 2007).
}

\author{
West Virginia Code \\ Title 56 \\ Legislative Rule \\ Office of Miners' Health, Safety and Training \\ Series 4 \\ Governing Protective Clothing and Equipment
}

\section{§ 56-4-8. Emergency Shelters.}

8.1 An emergency shelter shall be maintained within one thousand $(1,000)$ feet of the nearest working face in each working section. Such emergency shelter shall be approved by the Director and shall be constructed and maintained in a manner prescribed by the Director.

8.2 The Director may approve, as an alternative to a shelter, an additional surface opening located no more than 1,000 feet from the nearest working face and accurately located on escape-way maps as required in W.Va Code Chapter 22A Article 2-1.

8.3 The Director shall acquire, no later than July 1, 2006, the necessary technical/engineering support needed to evaluate the performance of emergency shelter components/systems, and to review the effectiveness of emergency shelter plans.

8.4 The Director shall, no later than July 10, 2006, issue an open opportunity for emergency shelter providers to submit products for approval. The Director shall maintain a current list of pending and approved emergency shelters on the West Virginia MHS\&T website http://www.wvminesafety.org.

8.5 Providers of emergency shelters seeking approval shall submit documentation prescribed by the Director that shall include a certification by an independent West Virginia licensed professional engineer that the proposed product meets the requirements set forth in Section 8, a description of the process used in making that determination and a certification in the following form: "I, the undersigned, herby certify that this product, to the best of my knowledge and belief, meets or exceeds all requirements set forth in W.Va CSR Title 56 Series 4-8."

8.6 Any emergency shelter approved by the Director shall:

8.6.1 Provide a minimum of 48 hours life support ( air, water, emergency medical supplies, and food) for the maximum number of miners reasonably expected on the working section;

8.6.2 Be capable of surviving an initial event with a peak overpressure of $15 \mathrm{psi}$ for 3 seconds and a flash fire as defined by the National Fire Protection Association standard NFPA- 2113 of 300 degrees Fahrenheit for 3 seconds; 
8.6.3 Be constructed such that it will be protected under normal handling and preevent mine conditions;

8.6.4 Provide for rapidly establishing and maintaining an internal shelter atmosphere of oxygen above $19.5 \%$, carbon dioxide below $0.5 \%$, carbon monoxide below 50 ppm, and an apparent-temperature of 95 degrees Fahrenheit ;

8.6.5 Provide the ability to monitor carbon monoxide and oxygen inside and outside the shelter;

8.6.6 Provide a means for entry and exit that maintains the integrity of the internal atmosphere;

8.6.7 Provide a means for MSHA certified intrinsically safe power if power required;

8.6.8 Provide a minimum eight quarts of water per miner;

8.6.9 Provide a minimum of 4,000 calories of food per miner;

8.6.10 Provide a means for disposal of human waste to the outside of the shelter;

8.6.11 Provide a first aid kit as defined at W.Va. Code Chapter 22A Article 259(3)(b) independent of the section first aid kit required by W.Va. Code Chapter 22A Article 2-59(3) and 2-60(f);

8.6.12 Have provisions for inspection of the shelter and contents;

8.6.13 Contain manufacturer recommended repair materials;

8.6.14 Provide a battery-powered occupant-activated strobe light of a model approved by the Director that is visible from the outside indicating occupancy;

8.6.15 Provide provisions for communication to the surface; and

8.6.16 Provide proof of current approval for all items and materials subject to MSHA approval. 


\section{Appendices B}

Appendix B-1 Beam Diagrams and Formulas for Simply Supported Beams with a Uniformly Distributed Load, (AISC, 1989).

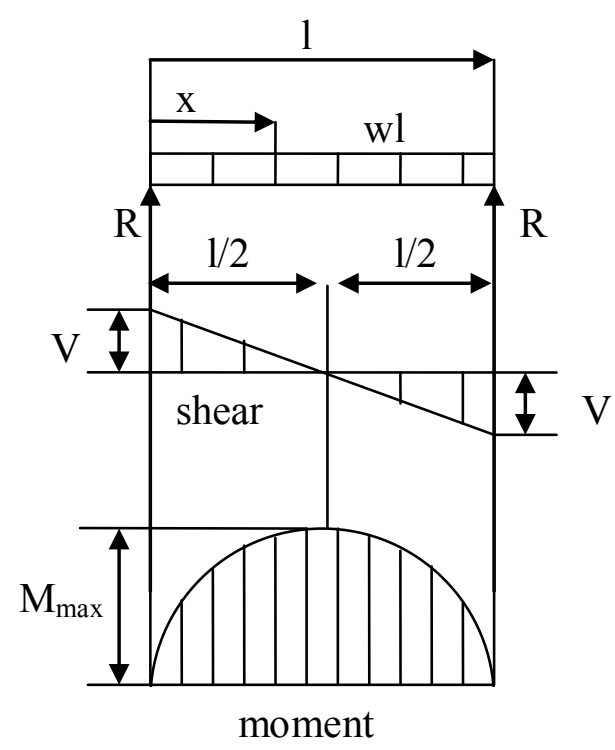

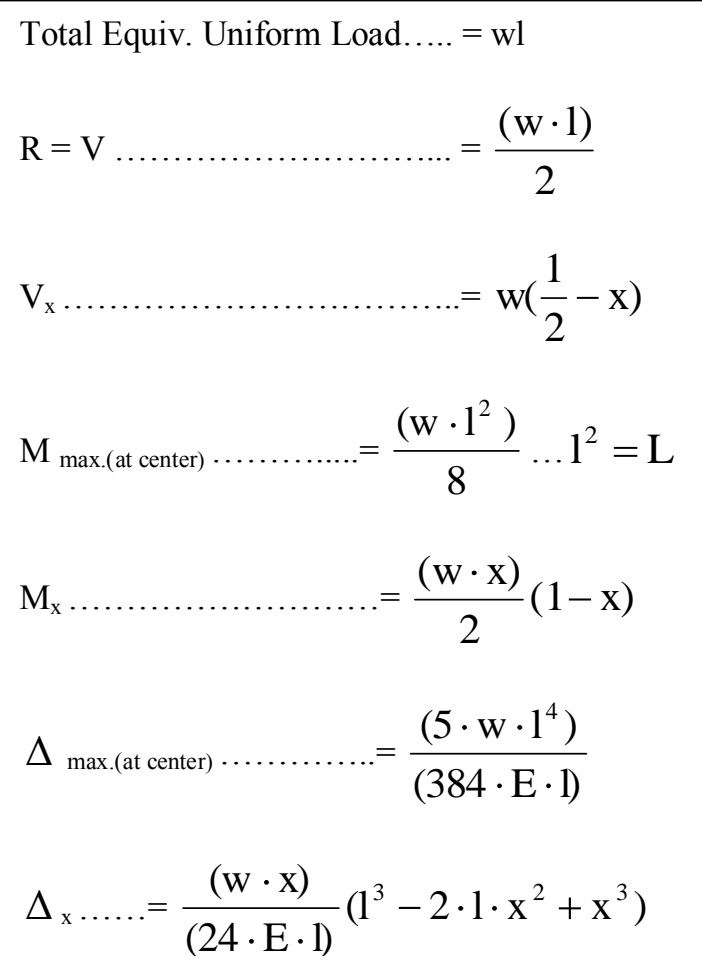




\section{Appendix B-2 Availability of shapes, plates, and bars according to ASTM structural steel specifications,}

\begin{tabular}{|c|c|c|c|c|c|c|c|c|c|c|c|c|c|c|c|c|c|}
\hline \multicolumn{18}{|c|}{ Availability of Shapes, Plates and Bars According to ASTM Structural Steel Specification } \\
\hline $\begin{array}{l}\text { Steel } \\
\text { Type }\end{array}$ & $\begin{array}{c}\text { ASTM } \\
\text { Designation }\end{array}$ & $\begin{array}{c}\text { Fy } \\
\text { Minimum } \\
\text { Yield }\end{array}$ & $\begin{array}{c}\mathrm{Fu} \\
\text { Tensile } \\
\text { Stress }^{\mathrm{a}}\end{array}$ & \multicolumn{3}{|c|}{ Shapes } & \multicolumn{11}{|c|}{ Plates and Bars } \\
\hline & & & & \multicolumn{3}{|c|}{$\begin{array}{c}\text { Group per ASTM } \\
\text { A6 }\end{array}$} & $\begin{array}{c}\text { To } \\
1 / 2^{\prime \prime} \\
\text { incl. }\end{array}$ & $\begin{array}{c}\text { Over } \\
1 / 2^{\prime \prime} \\
\text { to } \\
3 / 4^{\prime \prime} \\
\text { Incl. }\end{array}$ & $\begin{array}{c}\text { Over } \\
3 / 4 " \\
\text { to } \\
11 / 4 " \\
\text { Incl. }\end{array}$ & $\begin{array}{c}\text { Over } \\
11 / 4^{\prime \prime} \\
\text { to } \\
11 / 2 " \\
\text { Incl. }\end{array}$ & $\begin{array}{l}\text { Over } \\
11 / 2 " \\
\text { to 2" } \\
\text { Incl. }\end{array}$ & $\begin{array}{l}\text { Over } \\
2 " \text { to } \\
21 / 2 " \\
\text { Incl. }\end{array}$ & $\begin{array}{l}\text { Over } \\
21 / 2 " \\
\text { to } 4 " \\
\text { Incl. }\end{array}$ & $\begin{array}{c}\text { Over } \\
4 " \text { to } \\
5 " \\
\text { Incl. }\end{array}$ & $\begin{array}{c}\text { Over } \\
5 " \text { to } \\
6 " \\
\text { Incl. }\end{array}$ & \begin{tabular}{|c|} 
Over \\
$6 "$ to \\
$8 "$ \\
Incl.
\end{tabular} & $\begin{array}{c}\text { Over } \\
8^{\prime \prime}\end{array}$ \\
\hline & & & & \begin{tabular}{l|l}
$1^{\mathrm{b}}$ & 2 \\
2
\end{tabular} & \begin{tabular}{l|l|}
2 & 3 \\
\end{tabular} & \begin{tabular}{|l|l|}
4 & 5 \\
\end{tabular} & & & & & & & & & & & \\
\hline \multirow{3}{*}{ Carbon } & \multirow{2}{*}{ A36 } & 32 & $58-80$ & & & & & & & & & & & & & & \\
\hline & & 36 & $58-80^{c}$ & & & & & & & & & & & & & & \\
\hline & A529 & 42 & $60-85$ & & & & & & & & & & & & & & \\
\hline \multirow{9}{*}{$\begin{array}{c}\text { High } \\
\text { Strength } \\
\text { Low Alloy }\end{array}$} & \multirow{4}{*}{ A441 } & 40 & 60 & & & & & & & & & & & & & & \\
\hline & & 42 & 63 & & & & & & & & & & & & & & \\
\hline & & 46 & 67 & & & & & & & & & & & & & & \\
\hline & & 50 & 70 & & & & & & & & & & & & & & \\
\hline & $\begin{array}{l}\text { A572 } \\
\text { Grade }\end{array}$ & & & & & & & & & & & & & & & & \\
\hline & $\mathrm{A} 42$ & 42 & 60 & & & & & & & & & & & & & & \\
\hline & A50 & 50 & 65 & & & & & & & & & & & & & & \\
\hline & $\mathrm{A} 60$ & 60 & 75 & & & & & & & & & & & & & & \\
\hline & A65 & 65 & 80 & & & & & & & & & & & & & & \\
\hline \multirow{6}{*}{$\begin{array}{c}\text { Corrosion } \\
\text { Resistant } \\
\text { High } \\
\text { Strength } \\
\text { Low Alloy }\end{array}$} & \multirow{3}{*}{ A242 } & 42 & 63 & & & & & & & & & & & & & & \\
\hline & & 46 & 67 & & & & & & & & & & & & & & \\
\hline & & 50 & 70 & & & & & & & & & & & & & & \\
\hline & \multirow{3}{*}{ A588 } & 42 & 63 & & & & & & & & & & & & & & \\
\hline & & 46 & 67 & & & & & & & & & & & & & & \\
\hline & & 50 & 70 & & & & & & & & & & & & & & \\
\hline $\begin{array}{l}\text { Quenched } \\
\text { \& } \\
\text { Tempered } \\
\text { Low-Alloy }\end{array}$ & $A 852^{d}$ & 70 & $\begin{array}{l}90- \\
110\end{array}$ & & & & & & & & & & & & & & \\
\hline \multirow{2}{*}{$\begin{array}{l}\text { Quenched } \\
\text { \& } \\
\text { Tempered } \\
\text { Alloy }\end{array}$} & \multirow{2}{*}{ A514 } & 90 & $\begin{array}{c}100- \\
130\end{array}$ & & & & & & & & & & & & & & \\
\hline & & 100 & $\begin{array}{c}110- \\
130\end{array}$ & & & & & & & & & & & & & & \\
\hline & & These a & e availabl & & & & num & $\begin{array}{l}\text { less a } \\
\text { r-size sl } \\
\text { over } 42\end{array}$ & $\begin{array}{l}\text { range is } \\
\text { hapes. } \\
6 \mathrm{lbs} . \text { fft }\end{array}$ & & 9 of & Ksi & and & & & & \\
\hline & & These a & e not ava & ilable & & ${ }^{\mathrm{d}}$ Plates & s only. & & & & & & & & & & \\
\hline
\end{tabular}


Appendix B-3 Formulas for flat plates with straight boundaries and constant thickness, (Roark and Young, 1982).

This table represents a uniform load over the entire plate.

$$
\begin{aligned}
& F=\text { Freely Supported } \\
& \mathrm{S}=\text { Simply Supported }
\end{aligned}
$$



(Along free edge)

$$
\begin{aligned}
& \operatorname{Max} \sigma=\mathrm{S} * \mathrm{~F} / \mathrm{S} \\
& \max \mathrm{y}=\cos (\text { theta })
\end{aligned}
$$

$\operatorname{Max} \sigma=\mathrm{F} / \mathrm{S}$

(At center of plate)

$\operatorname{Max} \sigma=F / S$
$\max y=F \cos ($ theta $)$




\section{Appendices C}

Appendix C-1 MSHA Specifications for Quantity of Breathable Air , (MSHA, 2007).

I. Quantity of Breathable Air. In determining the quantity of breathable air necessary to sustain trapped miners, operators should consider specific mine conditions. The ERPs should identify all relevant variables that may impact the time required, under a variety of adverse conditions, to provide breathable air to trapped miners.

Below are some options that may satisfy the breathable air requirement:

1) An established borehole capable of providing fresh air to a location within 2,000 feet of the working section or a hardened room in accordance with the Emergency Mine Evacuation final rule (71 FR 71037, 71430, December 8, 2006), located within 2,000 feet of the working section.

2) Each miner should be provided a 48-hour supply of breathable air, if advance contingency arrangements have been made to reliably assure that miners who cannot be rescued within 48 hours will receive additional supplies of breathable air sufficient to sustain them until rescue. These contingency arrangements should be based on the following (other arrangements offering similar levels of protection also may suffice):

a) A pre-arranged, pre-surveyed area for barricading or other location that would isolate the miners from contaminated environments, located within 2,000 feet of the working section.

b) The capacity to promptly transport a drill rig to a pre-surveyed location such that a drilled hole would intersect the area designated for barricading (or other alternatives that would isolate the miners from contaminated environments).

3) Each miner should be provided a 96-hour supply of breathable air located within 2,000 feet of the working section.

4) The operator may use other methods to provide breathable air sufficient to sustain miners trapped underground for a period of time that reasonably would be expected to establish a fresh air source for trapped miners, as long as these methods provide equivalent safety protection. 
Appendix C-2 MSHA Specifications for Supplying Breathable Air (MSHA, 2007).

II. Location and Method of Providing Breathable Air. The ERPs should describe the operator's method for providing breathable air to trapped miners and establish the locations in which breathable air will be maintained. PPL 06-V-10 described some options through which miners could isolate themselves from contaminated/hazardous environments. ERPs should provide for breathable air within areas designated for barricading (or other alternatives that will isolate the miners from contaminated environments) and should establish the location of these areas. The locations of these areas should be shown on the escape map.

Within these areas, the supply of breathable air could be provided through various methods, including the following:

A. Boreholes with fresh air blowing fans capable of providing fresh air to trapped miners;

B. Buried or otherwise protected air lines supplied by surface positive pressure blowers and routed to locations that will isolate miners from contaminated environments;

C. Compressed air cylinders, oxygen cylinders, or chemical oxygen generators located at a designated area for barricading or other alternatives that would isolate miners from contaminated environments. When supplying breathable air through one of these methods, carbon dioxide scrubbing capability is necessary to prevent contamination of the isolated environment.

MSHA has issued further information in Hazard Awareness for Compressed Air and Compressed Oxygen, which is available at www.msha.gov. MSHA has also developed additional information concerning methods for providing breathable air. This additional information addresses calculations for developing quantity of breathable air, and includes scrubbing capability, where applicable. 


\section{VITA}

Mickey D. Mitchell-Cline was born and raised in Man, West Virginia where he finished high school. After completing his work at Man High School he entered West Virginia University in Morgantown, West Virginia in the Fall of 2001. He received the degree of Bachelors of Science in Electrical Engineering in May, 2006. In August, 2007, he entered graduate school at WVU to study for MS degree in Mining Engineering.

Permanent Address: $\quad$ Box 61

Man, West Virginia 25635 


\section{REFERENCES}

American Institute of Steel Construction (AISC), 1989, "Manual of Steel Construction", 1-305. American Institute of Steel Construction, New York, N.Y.

American Society of Heating, Refrigeration, and Air Conditioning Engineers, 1993, "ASHRAE Fundamentals, SI Edition", American Society of Heating, Refrigeration and Air Conditioning, 89-135. New York, N.Y.

DJF Consulting Limited, 2004, "Refuge Stations/Bays \& Safe Havens In Underground Coal Mining". 23 Nov. 2008. <http://www.rokdok.com/ucmsrc/refuge.pdf $>$.

Extend Air Corporation (EAC), 2007, "Lithium Hydroxide Curtains". 22 Feb. 2008. $<$ http://www.extendair.com/rescue.html $>$.

Hartman H.L., Mutmansky J.M., Ramani R.V., and Wang Y.J., 1997, "Mine Ventilation and Air Conditioning", 29-44. John Wiley and Sons, New York, NY.

Mine Safety and Health Administration (MSHA), 2007, "Program Information Bulletin (PIB) No. P07-03". 10 Oct. 2007.

$<$ http://www.msha.gov/regs/complian/PIB/2007/pib07-03.asp>.

Mine Safety and Health Administration (MSHA), 2006, "Mine Escape Planning and Emergency Workshop". 10 Feb. 2008.

$<$ http://www.msha.gov/regs/fedreg/notices/2006misc/06\%2D2905/workshopmaterial s.asp $>$.

Mine Safety and Health Administration (MSHA), 2007,"Methods for Providing

Breathable Air". 21 Jan. 2008.

$<$ http://www.msha.gov/regs/complian/PIB/2007/pib07-03attach2.pdf $>$.

Mine Safety and Health Administration (MSHA), 2007, "Program Information Bulletin (PIB) No. P07-05". 8 Feb. 2008.

$<$ http://www.msha.gov/regs/complian/PIB/2007/pib07-05.asp>.

Microsoft National Broadcasting Corporation (MSNBC), 2006, Associated Press. 9 Feb. 2008.

$<$ http://www.msnbc.msn.com/id/10988817/>.

Rendell D., Clarke M., and Evans M., 2007, "The Effect of Environmental Conditions on the Absorption of Carbon Dioxide Using Soda Lime", SAE Paper No. 2003-012644. 20-29.

Roark R.J., and Young W.C., 1982, “Formulas for Stress and Strain", 15.11 -15.36. McGraw-Hill, New York, NY. 
Strata Products USA, 2007, "List of Products and Services Available". 9 Sept. 2007. $<$ http://www.strataproducts.com/usa.htm>.

Steadman R.G., "The assessment of sultriness, Part 1: A temperature-humidity index based on human physiology and clothing science", Applied Meteorology Journal, 1979.23-39.

United States Environmental Protection Agency (EPA), 2007, "Carbon Monoxide." 10 Oct. 2007. <http://www.epa.gov/iaq/co.html>.

United States Environmental Protection Agency (EPA), 2007, "Carbon Dioxide as a Fire Suppressant: Examining the Risks." 8 Jan. 2008. $<$ http:/www.epa.gov/ozone/snap/fire/co2/co2report.html $>$.

West Virginia Office of Miners' Health, Safety and Training (WVOMHST), 2007, "Emergency Shelters." 9 Nov. 2007. <http://www.wvminesafety.org/>. 